\title{
Selenium inclusion decreases oxidative stress indicators and muscle injuries in sea bass larvae fed high-DHA microdiets
}

\author{
Mónica B. Betancor ${ }^{1 *}$, M $^{\mathrm{a}}$ José Caballero $^{1}$, Genciana Terova ${ }^{2}$, Reda Saleh ${ }^{1}$, Eyad Atalah ${ }^{1}$, \\ Tibiábin Benítez-Santana ${ }^{1}, \mathrm{~J}_{\text {. Gordon Bell }}^{3}$ and Marisol Izquierdo ${ }^{1}$ \\ ${ }^{1}$ Grupo de Investigación en Acuicultura, University of Las Palmas de Gran Canaria, Instituto Universitario de Sanidad \\ Animal, Trasmontaña s/n, 35413 Arucas, Las Palmas, Canary Islands, Spain \\ ${ }^{2}$ Department of Biotechnology and Molecular Sciences, University of Insubria, Via Dunant 3, 21100 Varese, Italy \\ ${ }^{3}$ Institute of Aquaculture, University of Stirling, Stirling FK9 4LA, UK
}

(Submitted 20 June 2011 - Final revision received 23 November 2011 - Accepted 30 November 2011 - First published online 13 March 2012)

\section{Abstract}

The objective of the present study was to determine the effect of Se inclusion in high-DHA and vitamin E microdiets $(5 \mathrm{~g}$ DHA/100 g dry weight and $300 \mathrm{mg}$ vitamin E/100 $\mathrm{g}$ dry weight; $5 \mathrm{~g} \mathrm{DHA} / 100 \mathrm{~g}$ dry weight and $300 \mathrm{mg}$ vitamin E/100 g dry weight supplemented with Se) in comparison with a control diet (1 g DHA/100 g dry weight and $150 \mathrm{mg}$ vitamin E/100 g dry weight) on sea bass larval growth, survival, biochemical composition, malonaldehyde (MDA) content, muscle morphology and antioxidant enzymes (AOE), insulin-like growth factors (IGF) and myosin expression. For a given DHA and vitamin E dietary content, Se inclusion favoured larval total length and specific growth rate, and reduced the incidence of muscular lesions, MDA contents and AOE gene expression. In contrast, IGF gene expression was elevated in the 5/300 larvae, suggesting an increased muscle mitogenesis that was corroborated by the increase in mRNA copies of myosin heavy chain. The results of the present study denoted the beneficial effect of Se not only in preventing oxidative stress, as a glutathione peroxidase cofactor, but probably due to other as yet unknown physiological functions.

Key words: Sea bass larvae: Oxidative stress: DHA: Selenium

Free radicals and/or oxygen derivatives are continuously generated during regular cellular metabolism. At low concentrations, these reactive oxygen species (ROS) may be beneficial or even indispensable in processes such as defence against microorganisms, contributing to phagocytic bactericidal activity. However, when an imbalance between ROS generation and ROS removal occurs, oxidative stress arises ${ }^{(1)}$. The detrimental effects include oxidative damage to molecules of great biological importance, including lipids, proteins and DNA, causing alterations that produce a range of cellular damage which can ultimately lead to cell death ${ }^{(2)}$.

Several effective antioxidant systems prevent oxidative damage in fish. Among them, various antioxidant enzymes (AOE) prevent the cascade of oxidation reactions, intercepting and inactivating the reactive intermediates and closing the lipidperoxidation catalytic cycle. This defence system includes enzymes such as catalase (CAT), superoxide dismutase (SOD) and glutathione peroxidase $(\mathrm{GPX})^{(2,3)}$. In addition to these enzymes, dietary micronutrients such as vitamins $\mathrm{E}$ and $\mathrm{C}$ as well as carotenoids have also been regarded as antioxidant defences in fish ${ }^{(4-8)}$. During larval stages, oxidation risks are particularly high, due to the increased metabolic rate, oxygen demand, water and long-chain PUFA (LC-PUFA) tissue contents found in fish larvae. Therefore, adequate supplementation of marine fish larvae with antioxidant elements is important when formulating diets in order to avoid in vivo lipid peroxidation. However, few studies have dealt with the effects of antioxidants in early fish feeding ${ }^{(9-12)}$. Among the other antioxidants, Se is an essential trace mineral in animal nutrition obtained partly from the surrounding water ${ }^{(13)}$, but mostly from the $\operatorname{diet}^{(14)}$. The importance of Se to oxidative stress involves its presence at the active site of the antioxidant enzyme $\mathrm{GPX}^{(15)}$, which reduces $\mathrm{H}_{2} \mathrm{O}_{2}$ at the expense of reduced glutathione $^{(16)}$. In fish, studies have shown a synergistic action

Abbreviations: 1/150, $1 \mathrm{~g}$ DHA/100 g dry weight and $150 \mathrm{mg}$ vitamin E/100 g dry weight diet; 5/300, 5 g DHA/100 g dry weight and 300 mg vitamin E/100 g dry weight diet; 5/300 + Se, $5 \mathrm{~g}$ DHA/100 g dry weight and $300 \mathrm{mg}$ vitamin E/100 g dry weight diet supplemented with Se; AOE, antioxidant enzymes; CAT, catalase; dph, days post-hatching; DW, dry weight; GLM, general linear model; GPX, glutathione peroxidase; IGF-I, insulin-like growth factor I; IGF-II, insulin-like growth factor II; LC-PUFA, long-chain PUFA; MDA, malonaldehyde; MyHC, myosin heavy chain; ROS, reactive oxygen species; SGR, specific growth rate; SOD, superoxide dismutase; TBARS, thiobarbituric acid-reactive substances.

*Corresponding author: M. B. Betancor, fax +34928 451143, email monica.betancor102@doctorandos.ulpgc.es 
between vitamin $\mathrm{E}$ and $\mathrm{Se}^{(17,18)}$. Moreover, a Se deficiency may lead to reduced levels of tissue $\alpha$-tocopherol in several fish species ${ }^{(3,17-20)}$. Additionally, a recent study in grouper (Epinephelus malabaricus) juveniles suggested a sparing effect between Se and vitamin $\mathrm{E}^{(21)}$.

One of the most important factors that can lead to oxidative stress in fish is their high requirement for LC-PUFA, which are high in diets and, subsequently, in fish tissue ${ }^{(22,23)}$. For instance, severe dystrophic lesions in the epaxial musculature of sea bass larvae have been related to the deleterious effect of oxidative stress due to the high ingestion of LC-PUFA, particularly $\mathrm{DHA}^{(12,24)}$. Muscle growth is an essential process during larval stages, as a massive increment of muscle fibres takes place from hatching to maturity ${ }^{(25)}$ with damage to the musculature appearing to compromise larval growth ${ }^{(12,24)}$.

Muscle formation processes require the influence of growth factors and a sequence of cellular events that result in the regulation of myoblasts (myosatellite cells) ${ }^{(26,27)}$. Insulin-like growth factors I and II (IGF-I and IGF-II) are two myogenic regulatory factors which increase satellite cell proliferation and differentiation $^{(28,29)}$. In various species of fish, it has been shown that hepatic $^{(30-33)}$ and muscular ${ }^{(32-34)}$ IGF-I and IGF-II mRNA levels depend on feeding status. Differences in the regulation of myogenesis such as myosin isoform expression have also been observed during the earliest stages of development as well as during temperature acclimatisation ${ }^{(35,36)}$. However, nutritional regulation of the various components of the IGF signalling pathways in muscle growth in fish as well as myosin expression is not well studied.

The purpose of the present study was to investigate whether diets supplemented with Se $(5 \mathrm{mg} / \mathrm{kg}$ dry weight (DW)) and vitamin $\mathrm{E}$ can protect sea bass larvae muscle from oxidative stress when high DHA levels are included in diets. To reach this objective, growth, survival, thiobarbituric acid-reactive substances (TBARS), fatty acid profile, $\alpha$-tocopherol and Se contents, and mRNA expression levels of CAT, SOD, GPX, IGF-I, $I G F-I I$ and myosin heavy chain $(M y H C$ ) genes were determined in sea bass larvae fed diets with different LC-PUFA, Se and vitamin E contents.

\section{Methods}

Fish

All experiments were designed according to the Animal Welfare Ethics Committee guidelines of Las Palmas University. The experiment was carried out at the Grupo de Investigación en Acuicultura facilities (Telde, Canary Islands, Spain). Sea bass (Dicentrarchus labrax) larvae were obtained from natural spawnings from the Instituto de Acuicultura de Torre de la Sal (Castellón, Spain). Before the start of the feeding experiment, larvae were fed enriched (DHA Protein Selco ${ }^{\circledR}$; INVE) yeastfed rotifers until they reached $14 \mathrm{~d}$ post-hatching (dph). Larvae (total length 8.58 (SD 0.64) $\mathrm{mm}$ and dry body weight 0.36 (SD $0 \cdot 0) \mathrm{mg}$ ) were randomly distributed into the experimental tanks at a density of 1000 larvae/tank and fed one of the experimental diets for $21 \mathrm{~d}$. All tanks (170 litres light grey colour cylinder fibreglass tanks) were supplied with filtered sea water (34 g/1 salinity) at an increasing rate of $1.0-1.5$ litres/min during the feeding trials. Water entered the tank from bottom to top; water quality was tested daily and no deterioration was observed. Water was continuously aerated $(125 \mathrm{ml} / \mathrm{min})$, attaining 5-8 g/l dissolved oxygen and saturation ranged between 60 and $80 \%$. Water temperature ranged from $19 \cdot 5$ to $21 \cdot 0^{\circ} \mathrm{C}$.

\section{Diets}

For the feeding experiment, three isonitrogenous and isolipidic experimental microdiets (pellet size $<250 \mu \mathrm{m}$ ) similar in their EPA content and different in DHA, Se and vitamin E content were formulated (Table 1) using concentrated fish oils INCROMEGA $^{\mathrm{TM}}$ EPA500 and DHA500 (CRODA) as sources of EPA and DHA in TAG form and DL- $\alpha$-tocopheryl acetate (Sigma-Aldrich) as a source of vitamin E. The diets were chosen based on previous trials $^{(12,24)}$ and their names elected according to the level of dietary DHA and vitamin E content. A positive control diet was formulated to include $1 \mathrm{~g}$ DHA/100 g DW and $150 \mathrm{mg}$ vitamin E/100 g DW (diet 1/150). The negative control diet consisted of $5 \mathrm{~g}$ DHA/100 $\mathrm{g}$ DW and $300 \mathrm{mg}$ vitamin E/100 $\mathrm{g}$ DW (diet 5/ 300). The third diet had identical DHA and vitamin E content to the 5/300 diet, but was supplemented with Se in organic

Table 1. Formulation of the experimental diets

\begin{tabular}{|c|c|c|c|}
\hline \multirow[b]{2}{*}{ Ingredients } & \multicolumn{3}{|c|}{ Experimental diets } \\
\hline & $1 / 150$ & $5 / 300$ & $5 / 300+\mathrm{Se}$ \\
\hline Defatted squid powder $(\mathrm{g} / 100 \mathrm{~g})^{*}$ & $69 \cdot 00$ & 68.85 & $68 \cdot 60$ \\
\hline $\begin{array}{l}\text { INCROMEGA }{ }^{\mathrm{TM}} \text { EPA 500TG } \\
\mathrm{g} / 100 \mathrm{~g}(\mathrm{DW}) \dagger\end{array}$ & $2 \cdot 80$ & $1 \cdot 80$ & $1 \cdot 80$ \\
\hline $\begin{array}{l}\text { INCROMEGA }{ }^{\mathrm{TM}} \text { DHA 500TG } \\
\mathrm{g} / 100 \mathrm{~g}(\mathrm{DW}) \dagger\end{array}$ & 0.20 & $6 \cdot 70$ & $6 \cdot 70$ \\
\hline Oleic acid (\%)‡ & $10 \cdot 00$ & 4.50 & 4.50 \\
\hline Soya lecithin§ & 2.00 & 2.00 & 2.00 \\
\hline Gelatine\|l & 3.00 & 3.00 & 3.00 \\
\hline 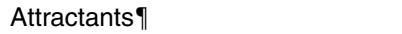 & 3.00 & 3.00 & 3.00 \\
\hline Taurine ${ }^{\star \star}$ & 1.50 & 1.50 & 1.50 \\
\hline Vitamin premix $\dagger \dagger$ & $6 \cdot 00$ & $6 \cdot 00$ & 6.00 \\
\hline Mineral premixł‡ & $2 \cdot 50$ & 2.50 & 2.50 \\
\hline Sel-Plex $2000^{\circledR}(\mathrm{g} / 100 \mathrm{~g})^{\S \S}$ & - & - & 0.25 \\
\hline Vitamin E mg/100 g (DW) ${ }^{||||}$ & - & 0.15 & 0.15 \\
\hline
\end{tabular}

DW, dry weight; $1 / 150,1 \mathrm{~g} \mathrm{DHA} / 100 \mathrm{~g} \mathrm{DW}$ and $150 \mathrm{mg}$ vitamin $\mathrm{E} / 100 \mathrm{~g}$ DW diet; $5 / 300,5 \mathrm{~g} \mathrm{DHA} / 100 \mathrm{~g} \mathrm{DW}$ and $300 \mathrm{mg}$ vitamin E/100 $\mathrm{g} \mathrm{DW}$ diet; $5 / 300+\mathrm{Se}, 5 \mathrm{~g}$ $\mathrm{DHA} / 100 \mathrm{~g} \mathrm{DW}$ and $300 \mathrm{mg}$ vitamin E/100 g DW diet supplemented with Se. ${ }^{*}$ Riber and Son.

† Croda Chemicals Europe.

‡ Merck.

$\S$ Acrofarma.

II Panreac.

I Attractant premix supplied per $100 \mathrm{~g}$ diet: inosine-5-monophosphate, $500.0 \mathrm{mg}$; betaine, $660.0 \mathrm{mg}$; L-serine, $170.0 \mathrm{mg}$; L-phenylalanine, $250.0 \mathrm{mg}$; DL-alanine, $500.0 \mathrm{mg}$; L-sodium aspartate, $330.0 \mathrm{mg}$; L-valine, $250.0 \mathrm{mg}$; glycine, $170.0 \mathrm{mg}$. ** Sigma-Aldrich.

t† Vitamin premix supplied per $100 \mathrm{~g}$ diet: cyanocobalamin, $0.03 \mathrm{mg}$; astaxanthin, $5.0 \mathrm{mg}$; folic acid, $5.4 \mathrm{mg}$; pyridoxine- $\mathrm{HCl}, 17.2 \mathrm{mg}$; thiamin, $21.7 \mathrm{mg}$; riboflavin, $72.5 \mathrm{mg}$; calcium-pantothenate, $101.5 \mathrm{mg}$; $p$-aminobenzoic acid, $145.0 \mathrm{mg}$; nicotinic acid, $290.1 \mathrm{mg}$; myo-inositol, $1450.9 \mathrm{mg}$; retinol acetate, $0.2 \mathrm{mg}$; ergocalcipherol, $3.6 \mathrm{mg}$; menadione, $17.3 \mathrm{mg}$; $\alpha$-tocopheryl acetate, $150.0 \mathrm{mg}$.

韧 Mineral premix supplied per $100 \mathrm{~g}$ diet: $\mathrm{NaCl}, 215.133 \mathrm{mg} ; \mathrm{MgSO}_{4} .7 \mathrm{H}_{2} \mathrm{O}$, $677.545 \mathrm{mg} ; \mathrm{NaH}_{2} \mathrm{PO}_{4} . \mathrm{H}_{2} \mathrm{O}$, 381.453 mg; $\mathrm{K}_{2} \mathrm{HPO}_{4}, 758.949 \mathrm{mg} ; \mathrm{Ca}\left(\mathrm{H}_{2} \mathrm{PO}_{4}\right) .2 \mathrm{H}_{2}$ $\mathrm{O}, 671.610 \mathrm{mg} ; \mathrm{FeC}_{6} \mathrm{H}_{5} \mathrm{O}_{7}, 146.884 \mathrm{mg} ; \mathrm{C}_{3} \mathrm{H}_{5} \mathrm{O}_{3} .0 .5 \mathrm{Ca}, 1617.210 \mathrm{mg} ; \mathrm{Al}_{2}$ $\left(\mathrm{SO}_{4}\right)_{3} .6 \mathrm{H}_{2} \mathrm{O}, 0.693 \mathrm{mg} ; \mathrm{ZnSO}_{4} .7 \mathrm{H}_{2} \mathrm{O}, 14.837 \mathrm{mg} ; \mathrm{CuSO}_{4} .5 \mathrm{H}_{2} \mathrm{O}, 1.247 \mathrm{mg}$; $\mathrm{MnSO}_{4} . \mathrm{H}_{2} \mathrm{O}, 2.998 \mathrm{mg} ; \mathrm{KI}, 0.742 \mathrm{mg} ; \mathrm{CoSO}_{4} .7 \mathrm{H}_{2} \mathrm{O}, 10.706 \mathrm{mg}$.

$\S \S$ Sel-Plex 2000, $2000 \mathrm{mg} \mathrm{Se} / \mathrm{kg}$; Alltech.

|||| DL- $\alpha$-Tocopheryl acetate; Sigma-Aldrich. 
form (diet 5/300 + Se, Sel-Plex ${ }^{\circledR} 2000,2000 \mathrm{mg} / \mathrm{kg}$; Alltech) The protein source was derived from squid meal, naturally containing $14 \%$ lipid, defatted three consecutive times to allow complete control of the microdiet fatty acid profile. No other ingredients were defatted due to their poor lipid content. The squid meal was defatted with a chloroform:squid meal ratio of $3: 1$, rinsed and dried in an oven at $37^{\circ} \mathrm{C}$ until complete solvent evaporation. EPA500 and DHA500 were added in different quantities to the defatted meal ( $2 \cdot 4 \%$ lipid content) to obtain the desired ratios. Oleic acid (Merck) was added to equalise the lipid content in each diet (Table 1) and soyabean lecithin (Acrofarma) was included as a source of phospholipids (Table 1). The microdiets were processed as described previously $^{(37)}$. Briefly, the squid powder and water-soluble components were mixed, followed by the lipid and fat-soluble vitamins and, before adding gelatine (Panreac), dissolved in warm water, as a binder. The paste was pelleted and oven dried at $38^{\circ} \mathrm{C}$ for $24 \mathrm{~h}$. The pellets were ground and sieved to obtain particle size below $250 \mu \mathrm{m}$. To avoid peroxidation, the diets were stored under $\mathrm{N}_{2}$ at $-20^{\circ} \mathrm{C}$ until use. The diets were analysed for proximate and fatty acid composition on a dry basis and manually supplied; fourteen times/d at $45 \mathrm{~min}$ intervals from 09.00 to 19.00 hours. Daily feed supplied was $2,2.5$ and $3 \mathrm{~g} /$ tank during the first, second and third week of feeding, respectively.

\section{Growth and survival}

Final survival was determined by counting live larvae at the beginning and end of the experiment. Growth was determined by measuring dry body weight $\left(105^{\circ} \mathrm{C}\right.$ for $\left.24 \mathrm{~h}\right)$ and total length (Profile Projector V-12A Tokyo; Nikon) of thirty fish/tank at the beginning, middle and end of the trial.

\section{Biochemical analysis}

All the remaining larvae in each tank were washed with distilled water, sampled and kept at $-80^{\circ} \mathrm{C}$ for biochemical composition, TBARS, Se and vitamin $\mathrm{E}$ analysis after $12 \mathrm{~h}$ of starvation at the end of the trial. Moisture ${ }^{(38)}$ protein $^{(38)}$ and lipid $^{(39)}$ contents of larvae and the diets were analysed.

Total lipid fatty acid analysis. Fatty acid methyl esters were obtained by transmethylation of total lipids as described by Christie $^{(40)}$. Fatty acid methyl esters were separated by GLC, quantified by flame ionisation detection (GC-14A; Shimadzu) under the conditions described previously ${ }^{(41)}$ and identified by comparison with previously characterised standards and GLC-MS.

Determination of vitamin E content. Vitamin E concentrations were determined in the diets and total larvae using HPLC at the University of Stirling (Scotland, UK). Samples were weighed, homogenised in pyrogallol and saponified as described by McMurray et al. ${ }^{(42)}$ for the diets or according to Cowey et al. ${ }^{(43)}$ for larval tissues. HPLC analysis was performed using a $150 \times 4.60 \mathrm{~mm}$ reversed-phase Luna $5 \mu \mathrm{m}$ C18 column (Phenomenox). The mobile phase was $98 \%$ methanol supplied at a flow rate of $1.0 \mathrm{ml} / \mathrm{min}$. The effluent from the column was monitored at a wavelength of $293 \mathrm{~nm}$ and quantification achieved by comparison with $(+)$ - $\alpha$-tocopherol (Poole) as the external standard.

Selenium determination. Total Se concentration was measured in total larvae and the diets, and analyses were carried out at the University of Stirling (Scotland, UK). Samples were acidified in a microwave digestor (MarsXpress; CEM) with $5 \mathrm{ml}$ of $69 \%$ pure $\mathrm{HNO}_{3}$, then poured after digestion into a $10 \mathrm{ml}$ volumetric flask and made up to volume with distilled water. A total of $0.4 \mathrm{ml}$ of this solution were then added to a $10 \mathrm{ml}$ sample tube, $10 \mu \mathrm{l}$ of the internal standard (Ga and Sc, $10 \mathrm{ppm}$ ) included and $0.3 \mathrm{ml}$ of methanol added. The tubes were made up to volume with distilled water and total Se measured by collision/reaction by inductively coupled plasma MS (Thermo Scientific) using argon and hydrogen as the carrier gas.

Measurement of thiobarbituric acid-reactive substances. TBARS from triplicate samples were determined using a method adapted from that used by Burk et al. ${ }^{(44)}$. Approximately 20-30 mg of larval tissue per sample were homogenised in $1.5 \mathrm{ml}$ of $20 \% \mathrm{TCA}(\mathrm{w} / \mathrm{v})$ containing $0.05 \mathrm{ml}$ of $1 \%$ butylated hydroxytoluene in methanol. To this $2.95 \mathrm{ml}$ of freshly prepared $50 \mathrm{~mm}$-thiobarbituric acid solution were added before mixing and heating for $10 \mathrm{~min}$ at $100^{\circ} \mathrm{C}$. After cooling, protein precipitates were removed by centrifugation (Sigma 4K15) at $2000 \boldsymbol{g}$ and the supernatant was read in a spectrophotometer (Evolution 300; Thermo Scientific) at $532 \mathrm{~nm}$. Absorbance was recorded against a blank at the same wavelength. The concentration of thiobarbituric acid-malonaldehyde (MDA), expressed as $\mu \mathrm{mol} \mathrm{MDA} / \mathrm{g}$ tissue was calculated using an extinction coefficient of $0 \cdot 156 \mathrm{~cm} / \mu \mathrm{M}$.

\section{Histopathological sampling}

From each tank, thirty larvae were collected every $7 \mathrm{~d}$ from the beginning of the feeding trial, fixed in $10 \%$ buffered formalin for $1-2 \mathrm{~d}$, dehydrated through graded alcohols, then xylene and finally embedded in paraffin wax. Then, six paraffin blocks containing five larvae/tank were sectioned at $3 \mu \mathrm{m}$, and stained with haematoxylin and eosin for histopathological evaluation $^{(45)}$

From each tank, ten larvae were fixed for $24 \mathrm{~h}$ at $4{ }^{\circ} \mathrm{C}$ in $2.5 \%$ glutaraldehyde in $0 \cdot 2 \mathrm{~m}$-phosphate buffer ( $\mathrm{pH} 7 \cdot 2$ ). Samples were then rinsed in phosphate buffer and post-fixed for $1 \mathrm{~h}$ in $2 \%$ osmium tetroxide in $0 \cdot 2 \mathrm{~m}$-potassium ferrocyanide. Each larva was then embedded in an Eppon/Araldite resin block. Thick serial transverse and longitudinal sections of the larvae were cut at $2 \mu \mathrm{m}$, stained with toluidine blue and examined by light microscopy ${ }^{(46)}$. Thin sections were cut at $50 \mathrm{~nm}$ and stained with lead citrate before observing with a ZEISS EM 910 transmission electron microscope (Zeiss) at the Electron Microscope Service of the University of Las Palmas de Gran Canaria.

\section{RNA extraction and quantitative RT-PCR}

Molecular biology analysis was carried out at the University of Insubria (Varese, Italy). Total RNA was extracted from sea bass larvae (approximately $200 \mathrm{mg}$; pool per tank), using the PureYield RNA Midiprep System (Promega). The quantity and 
purity of RNA was assessed by a spectrophotometer. Visualisation on $1 \%$ agarose gel stained with ethidium bromide showed that RNA was not degraded. After DNase treatment (Invitrogen), $3 \mu \mathrm{g}$ of total RNA were reverse transcribed into complementary DNA in a volume of $12 \mu \mathrm{l}$, including $1 \mu \mathrm{l}$ of oligo-dT16 primer $(50 \mathrm{pmol})$ and $1 \mu \mathrm{l}$ of $10 \mathrm{~mm}$-deoxynucleotide triphosphates. This mix was heated at $65^{\circ} \mathrm{C}$ for $5 \mathrm{~min}$ and chilled on ice before $4 \mu \mathrm{l}$ of $5 \times$ reverse transcription buffer, $2 \mu \mathrm{l}$ of $0 \cdot 1 \mathrm{~m}$-dithiothreitol, $1 \mu \mathrm{l}$ RNase out and $1 \mu \mathrm{l}$ of Moloney murine leukaemia virus was added. After incubation at $37^{\circ} \mathrm{C}$ for $50 \mathrm{~min}$, the reaction was stopped by heating at $75^{\circ} \mathrm{C}$ for $15 \mathrm{~min}$.

PCR primer sequences used for the PCR amplification of the complementary DNA of target genes were CAT, SOD, GPX, $I G F-I, I G F-I I$ and $M y H C$. To perform PCR, a $4 \mu \mathrm{l}$ aliquot of complementary DNA was amplified using $25 \mu \mathrm{l}$ GoTaq Green Master Mix (Promega) in $50 \mu \mathrm{l}$ of final volume and $50 \mathrm{pmol}$ of each designed primer.

A total of thirty-one PCR amplification cycles (eight touchdown) were performed for all primer sets, using an automated Thermal Cycler (MyCycler; BioRad). An aliquot of each sample was then subjected to electrophoresis on a $1 \%$ agarose gel in $1 \times$ Tris-acetate-EDTA buffer (Bio-Rad) and bands were detected by ethidium bromide staining. Samples were run with a $100 \mathrm{bp}-1.5 \mathrm{~kb}$ DNA ladder to control the molecular weight of DNA. The negative control (a reaction mixture without complementary DNA) confirmed the absence of genomic contamination. The PCR products from each primer set amplification were cloned using the $\mathrm{pGEM}^{\circledR}$-T easy vector (Promega) and subsequently sequenced in both directions (T7 and SP6).

TaqMan ${ }^{\circledR}$ real-time RT-PCR was performed on a StepOne Real Time PCR System (Applied Biosystems) using Assays-byDesign ${ }^{\text {SM }}$ PCR primers (Applied Biosystems) and gene-specific fluorogenic probes. Primer sequences and Taqman ${ }^{\circledR}$ probes of the target genes were as follows:

Target gene: sea bass $C A T$

Forward primer: 5'-ATGGTGTGGGACTTCTGGAG-3'

Reverse primer: 5'-GCTGAACAAGAAAGACACCTGATG-3'

Taqman ${ }^{\circledR}$ probe: $5^{\prime}$-CAGACACTCAGGCCTCA-3'

Target gene: sea bass $S O D$

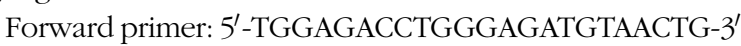

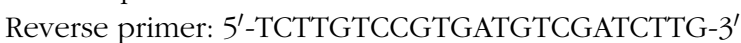

Taqman ${ }^{\circledR}$ probe: $5^{\prime}$-CAGGAGGAGATAACATTG-3'

Target gene: Sea bass GPX

Forward primer: 5'-AGTTAATCCGGAATTCGTGAG-3'

Reverse primer: 5'-AGCTTAGCTGTCAGGTCGTAAAAC- $3^{\prime}$

Taqman ${ }^{\circledR}$ probe: $5^{\prime}$-AATGGCTGGAAACGTG-3'

Target gene: Sea bass IGF-I

Forward primer: 5'-GCAGTTTGTGTGTGGAGAGAGA-3'

Reverse primer: 5'-GACCGCCGTGCATTGG-3'

Taqman ${ }^{\circledR}$ probe: $5^{\prime}$-CTGTAGGTTTACTGAAATAAAA- $3^{\prime}$

Target gene: Sea bass $I G F-I I$

Forward primer: 5'-TGCAGAGACGCTGTGTGG-3'

Reverse primer: $5^{\prime}$-GCCTACTGAAATAGAAGCCTCTGT- $3^{\prime}$

Taqman ${ }^{\circledR}$ probe: $5^{\prime}$-CAAACTGCAGCGCATCC- $3^{\prime}$

Target gene: Sea bass $M y H C$

Forward primer: 5'-TGGAGAAGATGTGCCGTACTCT-3' Reverse primer: 5'-CGTGTCATTGATTTGACGGACATTT-3'
Taqman ${ }^{\circledR}$ probe: $5^{\prime}$-AACTGAGTGAACTGAAGACC- 3 '

Data from TaqMan ${ }^{\circledR}$ PCR runs were collected using ABI's Sequence Detector Program. Cycle threshold values corresponded to the number of cycles at which fluorescence emission monitored in real time exceeded the threshold limit. The cycle threshold values were used to create standard curves to serve as a basis for calculating the absolute amounts of mRNA in total RNA. To reduce pipetting errors, master mixes were prepared to set up duplicate reactions $(2 \times 30 \mu \mathrm{l})$ for each sample.

\section{Calculations}

Larval survival was determined by comparing the number of larvae at the beginning of the trial with the larvae number measured in individual tanks at $35 \mathrm{dph}$ to which the average number of larvae sampled from the tanks during the trial was added. Percentage survival could then be calculated for each tank to get a mean and standard deviation per treatment. The incidence of muscular lesions was calculated as the percentage of injured larvae per tank compared with the total larvae observed, with standard deviation referring to deviation among the tanks. Specific growth rate (SGR) was calculated as

$$
\mathrm{SGR}=\left(\ln W_{1}-\ln W_{0}\right) \times 100 / t_{2}-t_{1},
$$

where $W_{0}$ and $W_{1}$ are the initial and final DW (tank means), respectively, and $t_{2}-t_{1}$ is the time interval in days between the beginning and end of the experimental trial (21d).

\section{Statistical analysis}

Survival, growth and molecular biology data were tested for normality and homogeneity of variances with Levene's test. Where necessary, data were log transformed before further statistical analysis. The $\chi^{2}$ test was employed for incidence of muscular lesions and TBARS content. Survival, growth and biochemical analysis data were treated using one-way ANOVA and molecular biology results were treated using a general linear model (GLM). Means were compared by Duncan's test. Results are presented as means and standard deviations. The tank was considered as the experimental unit, except for the estimation of the incidence of muscular lesions, where each individual larva was considered as a unit. For percentage data (final survival), arcsine transformation was performed before the analysis. For the analysis of one-way ANOVA, the following GLM was used:

$$
Y_{i j}=\mu+\alpha_{i}+\epsilon_{i j},
$$

where $Y_{i j}$ is the mean value of the tank, $\mu$ is the mean population, $\alpha_{i}$ is the fixed effect of the diet and $\boldsymbol{\epsilon}_{i j}$ is the residual error. For the analysis of molecular biology data, a two-variable GLM was employed to analyse possible interactions between treatment and time:

$$
Y_{i j k}=\mu+\alpha_{i}+\delta_{j}+(\alpha \delta)_{i j}+\epsilon_{i j k},
$$

where $Y_{i j k}$ is the mean value of the tank, $\mu$ is the mean population, $\alpha_{i}$ is the fixed effect of the diet, $\delta_{j}$ is the fixed effect of the time, $(\alpha \delta)_{i j}$ is the interaction between diet and time and $\boldsymbol{\epsilon}_{i j k}$ is the residual error. Significance was accepted at 
$P \leq 0 \cdot 05$. Statistical analysis was performed using SPSS software (SPSS for Windows 14.0; SPSS, Inc., 2005).

\section{Results}

The diet containing about $1 \%$ DHA (1/150) showed a higher monoenoic fatty acid level than the diets containing $5 \%$ DHA $(5 / 300$ and $5 / 300+\mathrm{Se})$ due to a higher oleic acid content in the former diet (Table 2). Elevation of dietary DHA $(5 / 300$ diet) increased $n-3$ and $n$ - 3 LC-PUFA fatty acid contents, as well as the $n-3: n-6$ ratio. Vitamin E levels were more than two times higher in the diets containing $300 \mathrm{mg} / 100 \mathrm{~g}$ compared with the control diet (1/150) (Table 3$)$. Se contents differed among the dietary treatments, with a higher level of this mineral found in the diet supplemented with Se compared with the others (Table 3).

All the experimental diets were well accepted by the larvae. Dietary increase of vitamin E or Se did not significantly affect larval survival ( $P=0 \cdot 158$; Table 5$)$. The highest larval growth, in terms of total length, was found in the larvae fed the positive control diet containing the lowest vitamin $\mathrm{E}$ and DHA contents (diet 1/150). However, increases in vitamin $\mathrm{E}$ and DHA (diet 5/ 300) significantly reduced the larval growth $(P=0 \cdot 001)$, whereas Se inclusion (diet $5 / 300+\mathrm{Se}$ ) significantly increased this parameter $(P=0.02 ;$ Table 5$)$. The average SGR was higher $(P=0.024)$ in the larvae fed the $1 / 150$ diet, although no differences were found in the larvae fed the $5 / 300+$ Se diet.

In terms of fatty acid composition, larvae fed the 5/300 diet resulted in a higher concentration of $n-3$ and $n-3$ LC-PUFA, reflecting the higher content of these components in the diets (Table 4). However, larvae fed the 1/150 diet showed a higher retention rate of DHA (279.26\%) and EPA (68.24\%) compared with larvae fed the $5 / 300$ ( 73.48 and $43.93 \%$, respectively) and $5 / 300+$ Se diets (77.00 and $44.75 \%$, respectively) and also a higher content of $18: 1 n$-9, displaying levels similar to those found in the former microdiet. In contrast, the 5/300 larvae showed a higher retention rate of arachidonic acid (about 50\%) compared with the 1/150 larvae (29.83\%).

The level of lipid oxidation, as indicated by the MDA content ( $\mu \mathrm{mol} / \mathrm{g}$ larval tissues), was significantly higher $(P=0.001)$ in the larvae fed the diets with the highest DHA content. Nevertheless, the inclusion of Se showed a beneficial effect preventing the formation of $\mathrm{H}_{2} \mathrm{O}_{2}$, as denoted by the decrease in MDA levels (Table 5). The lowest peroxidation level was observed in the larvae fed the $1 / 150$ diet. Despite the increase in dietary $\alpha$-tocopherol in the 5/300 and 5/300 + Se diets, the content of this nutrient in larvae did not significantly increase in comparison with larvae fed the $1 / 150 \operatorname{diet}(P=0 \cdot 601$; Table 5$)$. Therefore, the retention rate of dietary vitamin $\mathrm{E}$ in the larvae fed the $5 / 300$ $(17 \cdot 87 \%)$ and $5 / 300+$ Se $(17 \cdot 38 \%)$ diets was lower than the $1 / 150$ larvae $(44.68 \%)$. Sea bass larvae fed the diets supplemented with Se showed a significantly higher $(P=0.001)$ content of this mineral compared with the other larvae, this level being 1.7 times higher than the larvae fed the $1 / 150$ diet and $2 \cdot 4$ times higher than the 5/300 larvae (Table 5). Thus, although Se contents in the $1 / 150$ and 5/300 diets were similar, the larvae fed the latter diet showed lower Se levels together with the highest TBARS value.
Table 2. Main fatty acids (\% total fatty acids) of the experimental diets fed to sea bass larvae

\begin{tabular}{|c|c|c|c|}
\hline & \multicolumn{3}{|c|}{ Diets } \\
\hline & $1 / 150$ & $5 / 300$ & $5 / 300+\mathrm{Se}$ \\
\hline $14: 0$ & 1.54 & 1.26 & 0.78 \\
\hline $14: 1 n-7$ & 0.15 & 0.25 & 0.06 \\
\hline $14: 1 n-5$ & 0.22 & 0.35 & 0.09 \\
\hline $15: 0$ & 0.28 & 0.43 & $0 \cdot 15$ \\
\hline $15: 1 n-5$ & 0.02 & 0.14 & ND \\
\hline $16: 0$ ISO & 0.14 & 0.23 & 0.07 \\
\hline $16: 0$ & 7.86 & $5 \cdot 59$ & $5 \cdot 15$ \\
\hline $16: 1 n-7$ & 3.59 & $2 \cdot 26$ & 2.00 \\
\hline $16: 1 n-5$ & 0.19 & 0.23 & $0 \cdot 11$ \\
\hline $16: 2 n-4$ & 0.32 & 0.39 & 0.25 \\
\hline $17: 0$ & 1.21 & 0.82 & 0.65 \\
\hline $16: 3 n-3$ & 0.08 & 0.12 & 0.07 \\
\hline $16: 4 n-3$ & 0.09 & 0.13 & $0 \cdot 10$ \\
\hline $18: 0$ & 1.29 & 2.29 & $2 \cdot 21$ \\
\hline $18: 1 n-9+n-7$ & $55 \cdot 70$ & $31 \cdot 12$ & $29 \cdot 67$ \\
\hline $18: 1 n-5$ & 0.72 & 0.46 & 0.45 \\
\hline $18: 2 n-9$ & 0.25 & 0.13 & $0 \cdot 12$ \\
\hline $18: 2 n-6$ & $7 \cdot 40$ & 6.99 & $6 \cdot 87$ \\
\hline $18: 2 n-4$ & 0.46 & 0.28 & 0.26 \\
\hline $18: 3 n-6$ & 0.11 & 0.11 & 0.10 \\
\hline $18: 3 n-4$ & 0.13 & 0.10 & 0.09 \\
\hline $18: 3 n-3$ & 0.72 & 0.83 & 0.82 \\
\hline $18: 4 n-3$ & 0.83 & 0.94 & 1.00 \\
\hline $18: 4 n-1$ & 0.08 & 0.08 & 0.09 \\
\hline $20: 0$ & 0.10 & 0.31 & 0.29 \\
\hline $20: 1 n-9+n-7$ & 1.10 & 1.53 & 1.45 \\
\hline $20: 1 n-5$ & 0.05 & 0.12 & $0 \cdot 11$ \\
\hline $20: 2 n-9$ & 0.05 & 0.04 & 0.02 \\
\hline $20: 2 n-6$ & 0.09 & 0.21 & 0.21 \\
\hline $20: 3 n-6$ & 0.09 & 0.13 & 0.13 \\
\hline $20: 4 n-6$ & 0.71 & 1.57 & 1.50 \\
\hline $20: 3 n-3$ & 0.07 & 0.18 & $0 \cdot 16$ \\
\hline $20: 4 n-3$ & 0.32 & 0.52 & 0.55 \\
\hline $20: 5 n-3$ & $8 \cdot 66$ & 11.04 & $12 \cdot 20$ \\
\hline $22: 1 n-11$ & 0.17 & 0.51 & 0.50 \\
\hline $22: 1 n-9$ & 0.08 & 0.25 & 0.25 \\
\hline $22: 4 n-6$ & 0.02 & 0.19 & $0 \cdot 20$ \\
\hline $22: 5 n-6$ & 0.19 & 1.75 & 1.78 \\
\hline $22: 5 n-3$ & 0.32 & 1.29 & 1.43 \\
\hline $22: 6 n-3$ & 4.58 & 24.55 & 27.95 \\
\hline Saturated & $12 \cdot 28$ & $10 \cdot 70$ & 9.22 \\
\hline Monoenoics & 61.99 & $37 \cdot 23$ & 34.69 \\
\hline$n-3$ & $15 \cdot 68$ & 39.61 & $44 \cdot 27$ \\
\hline$n-6$ & $8 \cdot 61$ & $11 \cdot 14$ & $10 \cdot 85$ \\
\hline$n-9$ & $57 \cdot 19$ & 33.10 & 31.54 \\
\hline$n-3$ LC-PUFA & 13.96 & 37.58 & $42 \cdot 28$ \\
\hline ARA:EPA & 0.08 & 0.14 & 0.12 \\
\hline EPA:DHA & 1.89 & 0.45 & 0.44 \\
\hline Oleic:DHA & $12 \cdot 15$ & 1.27 & 1.06 \\
\hline Oleic: $n-3$ LC-PUFA & 3.99 & 0.83 & $0 \cdot 70$ \\
\hline$n-3: n-6$ & 1.82 & 3.56 & 4.08 \\
\hline
\end{tabular}

1/150, $1 \mathrm{~g} \mathrm{DHA} / 100 \mathrm{~g}$ dry weight and $150 \mathrm{mg}$ vitamin $\mathrm{E} / 100 \mathrm{~g}$ dry weight diet; $5 / 300,5 \mathrm{~g} \mathrm{DHA} / 100 \mathrm{~g}$ dry weight and $300 \mathrm{mg}$ vitamin $\mathrm{E} / 100 \mathrm{~g}$ dry weight diet; $5 / 300+\mathrm{Se}, 5 \mathrm{~g} \mathrm{DHA} / 100 \mathrm{~g}$ dry weight and $300 \mathrm{mg}$ vitamin $\mathrm{E} / 100 \mathrm{~g}$ dry weight diet supplemented with Se; ND, not determined; LC-PUFA, long-chain PUFA; ARA, arachidonic acid.

Histopathological examinations revealed the presence of lesions affecting the larval axial musculature. These lesions showed the typical features of necrotic degeneration of muscle, characterised by marked eosinophilia, loss of striations and adjacent nucleus. The incidence of muscular lesions increased with an increase in DHA dietary content (Table 5). 
Table 3. Gross composition, $\alpha$-tocopherol and selenium content in the experimental diets fed to sea bass larvae

(Mean values and standard deviations)

\begin{tabular}{|c|c|c|c|c|c|c|}
\hline & \multicolumn{2}{|c|}{$1 / 150$} & \multicolumn{2}{|c|}{$5 / 300$} & \multicolumn{2}{|c|}{$5 / 300+\mathrm{Se}$} \\
\hline & Mean & SD & Mean & SD & Mean & SD \\
\hline Protein (\%) & $66 \cdot 79$ & 0.52 & $67 \cdot 77$ & 0.09 & $66 \cdot 24$ & 0.36 \\
\hline Ash (\%) & 4.49 & 0.11 & 4.76 & $0 \cdot 12$ & $4 \cdot 87$ & 0.13 \\
\hline Moisture (\%) & $10 \cdot 31$ & 0.46 & 9.99 & 0.28 & 9.09 & 0.27 \\
\hline Lipids (\% DW) & 14.98 & 0.56 & $15 \cdot 80$ & 0.02 & 15.97 & 0.51 \\
\hline$\alpha$-Tocopherol $(\mu \mathrm{g} / \mathrm{g} D W)$ & $1410 \cdot 12$ & 38.77 & 3033.01 & 43.33 & $3217 \cdot 37$ & 14.45 \\
\hline Se $(\mu \mathrm{g} / \mathrm{mg})$ & 1.54 & $0 \cdot 12$ & 1.33 & 0.26 & $6 \cdot 27$ & 0.26 \\
\hline
\end{tabular}

However, inclusion of Se was shown to reduce this incidence to almost half.

In semithin sections, more detailed features of these muscular lesions could be observed. In the severely damaged fibres, a coagulation of the muscular proteins could be observed as a darkening of the surrounding fibres due to hypercontraction (Fig. 1(a)). In initial, mild stages of the condition, an increase in the presence of vacuoles within the fibres was observed, together with the loss of the shape of muscular fibres, alteration of sarcoplasmic membranes and variation in the diameter of fibres (Fig. 1(b)).

Transmission electron microscopy showed muscle degeneration with the presence of hydropic and autophagic vacuoles, considered secondary lysosomes, within some affected fibres in the larvae fed the 5/300 diet (Fig. 2(a)). Altered mitochondria, observed as swollen double membrane organelles, were seen in the affected fibres and presented loss of the cristae (Fig. 2(a)) in contrast to the normal ones (Fig. 2(b)). Additionally, satellite cells were observed to be attached to the existing damaged muscle fibres under the basal lamina (Fig. 2(c)).

The general pattern of antioxidant enzyme gene expression in all groups of sea bass larvae was characterised by a rapid increase between 14 and $26 \mathrm{dph}$, followed by a decrease back to the levels slightly higher than those observed at $14 \mathrm{dph}$, by 29 dph (Fig. 3(a)-(c)). The only exception to this trend was observed in GPX gene expression, where sea bass larvae fed the $1 / 150$ diet had a lower mRNA level of this enzyme at $35 \mathrm{dph}$ in comparison with that at $14 \mathrm{dph}$ (Fig. 3(c)). CAT gene expression was higher in the larvae fed the diets containing a high content of DHA at all sampling points, although no statistical differences were observed (Fig. 3(a)). However, GLM analysis showed differences between all the three treatments $(P=0.001$; Fig. 3(a); Table 6$)$. The SOD mRNA copy number was significantly higher $(P=0.004)$ at $35 \mathrm{dph}$ in the $5 / 300$ larvae (Fig. 3(b)). GPX expression level was highest in the larvae fed the diets containing a high level of DHA compared with larvae fed low DHA levels. Nevertheless, the larvae fed the diets supplemented with Se showed a lower number of GPX mRNA copies, comparable with the larvae fed the 1/150 diet (Fig. 3(c)).

Regarding the IGF genes, IGF-I mRNA copy number increased from 14 to $26 \mathrm{dph}$ in all treatments, showing a decrease at day 35 in the 1/150 and 5/300 + Se larvae. In contrast, the 5/300 larvae showed an increasing IGF-I expression levels throughout the experimental trial, with significantly higher levels at $35 \mathrm{dph}(P=0.006$; Fig. 3(d)). No significant differences were observed among the treatments taking into account the whole experimental period (Fig. 3(d); Table 6). The mRNA levels of IGF-II followed a similar increasing pattern in the $5 / 300$ and $5 / 300+$ Se larvae from 14 to $26 \mathrm{dph}$, in contrast to the $1 / 150$ larvae. At $26 \mathrm{dph}$, the $5 / 300+$ Se larvae showed a marked decrease in IGF-II expression, whereas in the $5 / 300$ larvae, a steady increase could be observed. In the larvae fed the $1 / 150$ diet, a decrease in IGF-II expression could be observed at all sampling points (Fig. 3(e)).

MyHC expression levels were elevated in the larvae fed the 5/ 300 diet, with a lower expression of this gene mRNA copy number was found at $26 \mathrm{dph}$, when se was included in the diet $(P=0 \cdot 007)$. At $35 \mathrm{dph}$, no statistical differences were observed when Se was added to the 5/300 diet, with the lowest values in the 1/150 larvae (Fig. 3(f)). GLM analysis showed significant differences between the 5/300 larvae and the larvae fed the other dietary treatments $(P=0 \cdot 001$; Fig. 3(f); Table 6).

Interactions were found in the gene expression between dietary treatment and time within the experimental trial for SOD and IGF-I (Table 6), indicating that the increase in the expression of these genes may be induced for the larval stage and the effect of the diet. However, IGF-I showed no differences in the expression among the treatments or during the whole experimental trial (Table 6).

\section{Discussion}

The aim of the present study was to evaluate the oxidative status of sea bass larvae when Se and vitamin E were included in the diet, at high DHA level inclusion. Previously, Betancor et $a l .{ }^{(12,24)}$ provided evidence of the appearance of muscular dystrophy in sea bass larvae when fed high DHA, implying that an excessive production of free radicals was present. Furthermore, the same authors showed that an increase in vitamin $\mathrm{E}$ alone could not prevent its adverse effects. Se and vitamin $\mathrm{E}$ have different but complementary biochemical functions which may allow these nutrients to interact physiologically ${ }^{(47)}$. 
Table 4. Main fatty acid compositions of total lipids from sea bass larvae fed the experimental diets for $21 \mathrm{~d}$ (\% total fatty acids)

(Mean values and standard deviations)

\begin{tabular}{|c|c|c|c|c|c|c|c|c|c|}
\hline & \multicolumn{2}{|c|}{ Initial } & \multicolumn{2}{|c|}{$1 / 150$} & \multicolumn{2}{|c|}{$5 / 300$} & \multicolumn{2}{|c|}{$5 / 300+\mathrm{Se}$} & \multirow[b]{2}{*}{$F$} \\
\hline & Mean & SD & Mean & SD & Mean & SD & Mean & SD & \\
\hline $14: 0$ & 1.08 & 0.01 & 0.93 & 0.06 & 0.76 & 0.03 & 0.71 & 0.03 & 7.092 \\
\hline $14: 1 n-7$ & 0.33 & 0.01 & 0.08 & 0.01 & 0.08 & 0.03 & 0.09 & 0.04 & 0.472 \\
\hline $14: 1 n-5$ & 0.07 & 0.00 & 0.07 & 0.02 & 0.04 & 0.01 & 0.06 & 0.00 & 1.407 \\
\hline $15: 0$ & $0 \cdot 18$ & 0.12 & 0.63 & 0.29 & 0.98 & 1.22 & 0.22 & 0.05 & $2 \cdot 126$ \\
\hline $15: 1 n-5$ & 0.08 & 0.00 & 0.12 & $0 \cdot 10$ & 0.09 & 0.06 & 0.06 & 0.00 & 0.634 \\
\hline $16: 0$ & $16 \cdot 4$ & 3.31 & 17.51 & 2.44 & $17 \cdot 61$ & 0.25 & 16.56 & 0.42 & 0.152 \\
\hline $16: 1 n-7$ & $9 \cdot 67$ & 1.75 & 2.02 & $0 \cdot 14$ & 1.60 & 0.06 & 1.56 & 0.00 & 9.531 \\
\hline $16: 1 n-5$ & 0.54 & 0.06 & 0.25 & 0.01 & 0.25 & 0.01 & 0.29 & 0.10 & 1.788 \\
\hline $16: 2 n-6$ & 0.92 & 0.23 & $0 \cdot 30$ & 0.00 & 0.36 & 0.04 & 0.37 & 0.02 & 1.025 \\
\hline $16: 2 n-4$ & 0.89 & 0.17 & 0.93 & 0.40 & 0.96 & 0.15 & 0.81 & 0.06 & 0.248 \\
\hline $17: 0$ & 0.98 & 0.11 & $0.91^{a}$ & $0 \cdot 10$ & $0.80^{\mathrm{a}}$ & 0.03 & $0.75^{\mathrm{b}}$ & 0.00 & $15 \cdot 532$ \\
\hline $16: 3 n-3$ & 0.06 & 0.00 & 0.12 & 0.01 & 0.14 & 0.03 & 0.12 & 0.03 & 0.764 \\
\hline $16: 3 n-1$ & 0.07 & 0.01 & $0 \cdot 10$ & 0.02 & 0.54 & 0.10 & 0.64 & 0.05 & 0.589 \\
\hline $16: 4 n-3$ & 0.41 & 0.16 & 0.62 & 0.35 & 0.44 & 0.10 & 0.56 & 0.03 & 0.573 \\
\hline 18:0 & $7 \cdot 34$ & 0.72 & 11.66 & 3.41 & $12 \cdot 29$ & 0.36 & $11 \cdot 37$ & 0.39 & 0.265 \\
\hline $18: 1 n-9$ & $16 \cdot 14$ & 2.01 & $26 \cdot 35^{\mathrm{a}}$ & $4 \cdot 87$ & $20 \cdot 92^{\mathrm{b}}$ & 0.51 & $19 \cdot 36^{b}$ & 0.32 & 11.452 \\
\hline $18: 1 n-7$ & $6 \cdot 27$ & 0.48 & 4.85 & 0.29 & 4.44 & 0.39 & 3.98 & 0.29 & 0.900 \\
\hline $18: 1 n-5$ & 0.58 & 0.17 & 0.62 & 0.24 & 0.49 & 0.07 & 0.54 & 0.02 & 0.626 \\
\hline $18: 2 n-6$ & 3.75 & 1.14 & $4 \cdot 23^{\mathrm{a}}$ & 0.08 & $3.90^{\mathrm{b}}$ & 0.17 & $3.75^{\mathrm{b}}$ & 0.08 & 11.072 \\
\hline $18: 2 n-4$ & 0.19 & 0.09 & 0.04 & 0.05 & 0.06 & 0.01 & 0.07 & 0.00 & $1 \cdot 126$ \\
\hline $18: 3 n-6$ & 0.17 & 0.08 & 0.43 & 0.01 & 0.38 & 0.04 & 0.32 & 0.02 & 0.399 \\
\hline $18: 3 n-4$ & 0.09 & 0.01 & 0.07 & 0.04 & 0.06 & 0.02 & 0.08 & 0.00 & 0.225 \\
\hline $18: 3 n-3$ & 0.8 & 0.27 & $0.32^{\mathrm{b}}$ & 0.05 & $0.44^{\mathrm{a}, \mathrm{b}}$ & 0.04 & $0.49^{\mathrm{a}}$ & 0.03 & $13 \cdot 717$ \\
\hline $18: 4 n-3$ & 0.22 & 0.09 & 0.29 & 0.06 & 0.29 & 0.13 & 0.37 & 0.04 & 2.413 \\
\hline $20: 0$ & $0 \cdot 18$ & 0.08 & 0.38 & 0.19 & 0.47 & 0.01 & 0.47 & 0.08 & 0.647 \\
\hline $20: 1 n-9+n-7$ & 1.97 & 0.51 & 1.83 & 0.00 & 1.77 & 0.06 & 1.77 & 0.21 & 0.063 \\
\hline $20: 1 n-5$ & 0.49 & 0.26 & 0.26 & $0 \cdot 15$ & $0 \cdot 13$ & 0.01 & $0 \cdot 16$ & 0.00 & 1.268 \\
\hline $20: 2 n-6$ & 0.71 & 0.38 & 0.50 & 0.13 & 0.65 & 0.08 & 0.67 & 0.07 & 1.881 \\
\hline $20: 3 n-6$ & 0.24 & 0.12 & 0.08 & 0.01 & 0.08 & 0.00 & 0.08 & 0.01 & 0.263 \\
\hline $20: 4 n-6$ & 3.34 & 0.72 & $2 \cdot 38^{\mathrm{b}}$ & 0.04 & $3.07^{\mathrm{a}}$ & 0.22 & $3.03^{\mathrm{a}}$ & 0.03 & $9 \cdot 277$ \\
\hline $20: 3 n-3$ & 0.09 & 0.00 & 0.12 & 0.09 & $0 \cdot 15$ & 0.04 & 0.14 & 0.01 & 0.304 \\
\hline $20: 4 n-3$ & 0.34 & 0.11 & 0.14 & 0.00 & $0 \cdot 16$ & 0.01 & 0.16 & 0.00 & 0.125 \\
\hline $20: 5 n-3$ & $7 \cdot 60$ & 0.33 & $5 \cdot 91^{\mathrm{a}}$ & $1 \cdot 18$ & $4.85^{\mathrm{b}}$ & 0.20 & $5 \cdot 46^{a, b}$ & 0.36 & 0.063 \\
\hline $22: 1 n-11$ & 0.14 & 0.09 & $0.46^{\mathrm{a}}$ & 0.30 & $0.19^{b}$ & 0.08 & $0.23^{\mathrm{b}}$ & 0.01 & $177 \cdot 782$ \\
\hline $22: 1 n-9$ & 0.33 & 0.17 & 0.26 & 0.15 & 0.26 & 0.06 & 0.23 & 0.08 & 1.548 \\
\hline $22: 5 n-6$ & 0.58 & 0.28 & 1.09 & 0.09 & 1.26 & 0.07 & 1.40 & 0.03 & 1.074 \\
\hline $22: 5 n-3$ & 1.58 & 0.33 & 0.64 & 0.26 & 0.57 & 0.06 & 0.69 & 0.02 & 0.347 \\
\hline $22: 6 n-3$ & $14 \cdot 22$ & $4 \cdot 36$ & $12 \cdot 79^{\mathrm{b}}$ & 0.37 & $18 \cdot 04^{\mathrm{a}, \mathrm{b}}$ & 1.19 & $21 \cdot 80^{\mathrm{a}}$ & 0.94 & $11 \cdot 845$ \\
\hline Saturated & $26 \cdot 17$ & 5.43 & $32 \cdot 01$ & $6 \cdot 29$ & 32.91 & 1.54 & 30.08 & 0.76 & 0.333 \\
\hline Monoenoics & 36.62 & 3.61 & $36 \cdot 73^{\mathrm{a}}$ & 4.51 & $30 \cdot 20^{b}$ & 0.55 & $28 \cdot 26^{\mathrm{b}}$ & 0.39 & $23 \cdot 716$ \\
\hline$n-3$ & $25 \cdot 39$ & $2 \cdot 48$ & $20 \cdot 94^{\mathrm{c}}$ & $2 \cdot 23$ & $25 \cdot 11^{b}$ & 1.43 & $29 \cdot 78^{a}$ & 1.25 & $26 \cdot 669$ \\
\hline$n-6$ & $9 \cdot 70$ & 1.22 & 8.45 & 0.97 & $9 \cdot 80$ & 0.47 & 9.74 & 0.04 & 1.562 \\
\hline$n-9$ & $18 \cdot 81$ & 4.97 & $28 \cdot 44^{\mathrm{a}}$ & 4.72 & $23.08^{b}$ & 0.39 & $21 \cdot 58^{c}$ & 0.04 & $12 \cdot 277$ \\
\hline$n-3$ LC-PUFA & 23.74 & 5.94 & $12 \cdot 92^{\mathrm{C}}$ & 7.45 & $23 \cdot 78^{\mathrm{b}}$ & 1.42 & $28 \cdot 25^{\mathrm{a}}$ & 1.30 & $73 \cdot 731$ \\
\hline Oleic:DHA & $1 \cdot 13$ & 0.21 & $1.76^{\mathrm{a}}$ & 0.08 & $1 \cdot 16^{\mathrm{b}}$ & 0.10 & $0.89^{c}$ & 0.05 & $46 \cdot 781$ \\
\hline Oleic: $n$-3 LC-PUFA & 0.68 & 0.06 & $2 \cdot 58^{a}$ & 1.86 & $0.88^{b}$ & 0.07 & $0.69^{b}$ & 0.04 & $12 \cdot 042$ \\
\hline$n-3: n-6$ & $2 \cdot 62$ & 0.71 & $2 \cdot 51$ & 0.55 & 2.56 & 0.05 & 3.06 & 0.12 & 0.776 \\
\hline
\end{tabular}

Se contents in the 5/300 + Se diet were adjusted according to the levels found in copepods ${ }^{(48,49)}$, natural live prey of marine fish larvae, although they were higher than those recommended by the National Research Council ${ }^{(50)}$ for juveniles of other fish species. Since marine fish larvae have a rapid growth rate, it is possible that they may well have a higher requirement than the juveniles which have been used in most of the requirement studies quoted by the National Research Council. In addition, the Se level did not seem to be excessive, as the larvae fed this diet did not show reduced growth in comparison with the larvae fed the same vitamin E and DHA contents. Reduced growth is one of the first symptoms occurring when excessive levels of Se are fed to fish ${ }^{(11,21,51-53)}$. Moreover, the Se source used in the present study was derived from yeast, making it less likely to be toxic as Se toxicity is highly dependent on its speciation $^{(54)}$, with mineral Se being more toxic than organic $\mathrm{Se}^{(51,55)}$.

A dose-dependent effect of dietary vitamin $\mathrm{E}$ on larval tissue concentration was not observed in the present study, with the highest vitamin E content found in the larvae fed the lowest 
Table 5. Sea bass larvae performance and levels of lipid peroxidation products (thiobarbituric acid-reactive substances (TBARS)), vitamin E ( $\alpha$-tocopherol) and selenium content of sea bass larvae at the beginning and after eating the experimental diets for $21 \mathrm{~d}$ (Mean values and standard deviations)

\begin{tabular}{|c|c|c|c|c|c|c|c|c|}
\hline & \multicolumn{8}{|c|}{ Diets } \\
\hline & \multicolumn{2}{|c|}{ Initial } & \multicolumn{2}{|c|}{$1 / 150$} & \multicolumn{2}{|c|}{$5 / 300$} & \multicolumn{2}{|c|}{$5 / 300+\mathrm{Se}$} \\
\hline & Mean & SD & Mean & SD & Mean & SD & Mean & SD \\
\hline \multicolumn{9}{|l|}{ Results of the dietary trial } \\
\hline Larval total length $(\mathrm{mm})$ & $8 \cdot 58$ & 0.64 & $12 \cdot 60^{\mathrm{a}}$ & 0.93 & $10 \cdot 89^{c}$ & $1 \cdot 24$ & $11 \cdot 35^{\mathrm{b}}$ & $1 \cdot 29$ \\
\hline Larval dry weight (mg) & 0.36 & 0.00 & 1.46 & 0.47 & 0.94 & 0.05 & 1.08 & $0 \cdot 10$ \\
\hline SGR & - & - & $6.79^{\mathrm{a}}$ & $1 \cdot 15$ & $4.55^{b}$ & 0.27 & $5 \cdot 24^{a, b}$ & 0.44 \\
\hline Survival (\%) & - & - & 60.51 & $9 \cdot 10$ & 48.42 & 4.00 & 49.03 & 8.02 \\
\hline Incidence of muscular lesions (\%) & - & - & $15 \cdot 7^{\mathrm{b}}$ & $14 \cdot 14$ & $52 \cdot 63^{\mathrm{a}}$ & $15 \cdot 93$ & $27 \cdot 6^{\mathrm{a}, \mathrm{b}}$ & $6 \cdot 94$ \\
\hline Vitamin E ( $\alpha$-tocopherol) ( $\mu \mathrm{g} / \mathrm{g}$ dry weight) & 111.45 & 43.26 & $630 \cdot 24$ & $12 \cdot 39$ & $542 \cdot 10$ & 80.51 & $559 \cdot 23$ & 88.58 \\
\hline TBARS (nmol/g dry weight) & 62.85 & 0.61 & $166 \cdot 62^{c}$ & $25 \cdot 08$ & $2402 \cdot 15^{a}$ & 67.91 & $282 \cdot 29^{b}$ & 92.48 \\
\hline Se ( $\mu \mathrm{g} / \mathrm{mg}$ dry weight) & 1.38 & $0 \cdot 10$ & $1.58^{\mathrm{b}}$ & 0.12 & $1 \cdot 11^{\mathrm{c}}$ & 0.31 & $2 \cdot 65^{\mathrm{a}}$ & 0.27 \\
\hline
\end{tabular}

level of vitamin $\mathrm{E}(150 \mathrm{mg} / 100 \mathrm{~g} \mathrm{DW})$. These results are in contrast with previous reports where vitamin $\mathrm{E}$ concentrations in fish were linked to dietary input ${ }^{(56,57)}$. It is also noteworthy that vitamin E levels were influenced by the dietary DHA ratio, being lower in the larvae fed the diets containing the higher amount of DHA (5/300 diet). This indicates that more vitamin $\mathrm{E}$ was being utilised as an antioxidant in the larvae fed higher DHA levels to protect tissue lipids from an increased oxidation risk. Consequently, $\alpha$-tocopherol was accumulated at lower amounts in larval tissues. These results match those of previous reports where vitamin E concentration in juvenile or adult fish was lower when high contents of $n$-3 LC-PUFA were included in the diets ${ }^{(57)}$. In addition, the low DHA retention rate observed in the 5/300 larvae could probably be due to the high in vivo lipid oxidation induced by this fatty acid.

In agreement with this, a dietary DHA increase resulted in higher levels of MDA, whereas Se supplementation improved protection against peroxidation by decreasing TBARS values. Moreover, Se incorporation rate was very low in the 5/ $300+$ Se larvae $(42 \cdot 26 \%)$ in contrast to the $1 / 150$ (100\%) and $5 / 300(83.46 \%)$ larvae, suggesting that this mineral was being used at the active sites of the antioxidant enzyme GPX ${ }^{(15)}$. The synergism between tocopherol and Se has previously been observed in rainbow trout (Oncorbynchus mykiss) and salmon (Salmo salar) using diets deficient in vitamin E, Se or both $^{(17,18)}$. In the present study, tocopherol levels were high enough to avoid a deficiency in this nutrient, suggesting that vitamin $\mathrm{E}$ addition as the sole antioxidant is not sufficient enough to control lipid peroxidation when high levels of DHA are included in fish larval diets. Therefore, the role of tocopherol as an effective antioxidant depends on the extent of oxidative stress in fish and is thus related to the degree of unsaturation of dietary fatty acids.

The availability of the literature on the activities of AOE in fish is mainly focused on pollutant detoxification ${ }^{(58,59)}$ or developmental aspects ${ }^{(9,60)}$. A few reports exist concerning the effect of dietary components on their activity and gene expression during early developmental stages of marine fish larvae ${ }^{(61)}$. The results from the present study demonstrate that there is an increase in the expression of specific antioxidant genes in sea bass larvae exposed to oxidative stress in order to neutralise the generated ROS. Moreover, when sea bass larvae were exposed to high dietary DHA contents (5\%), the induction of antioxidant enzyme genes coincided with increases in MDA levels. Accordingly, studies in Manchurian trout (Brachymystax lenok) larvae ${ }^{(62)}$ revealed that high dietary lipid levels produced elevated MDA levels, inducing an antioxidant response noticeable by an increase in the activity of AOE.
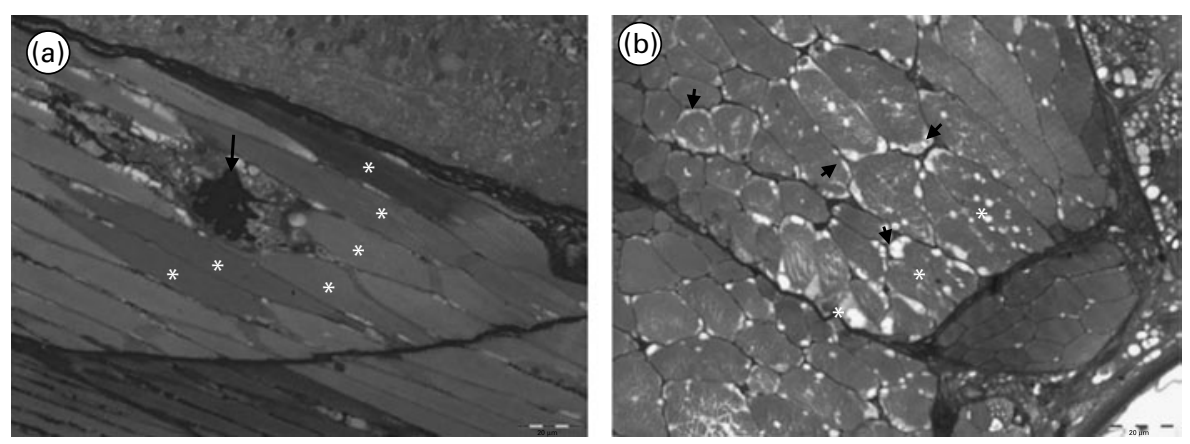

Fig. 1. Semithin micrographs of (a) longitudinal and (b) transversal sections $(400 \times)$ from larvae fed the diet $5 / 300(5 \mathrm{~g} \mathrm{DHA} / 100 \mathrm{~g}$ dry weight and $300 \mathrm{mg}$ vitamin $\mathrm{E} / 100 \mathrm{~g}$ dry weight) showing (a) coagulation of muscular proteins in the affected fibre $(\rightarrow)$ and hypercontraction of the surrounding muscular fibres ( $\left.{ }^{*}\right)$. (b) Mild affected fibres showed loss of the polyhedral structure, abundant vacuoles $\left(^{*}\right)$ and dilatation of sarcoplasmic membranes $(\rightarrow)$. 

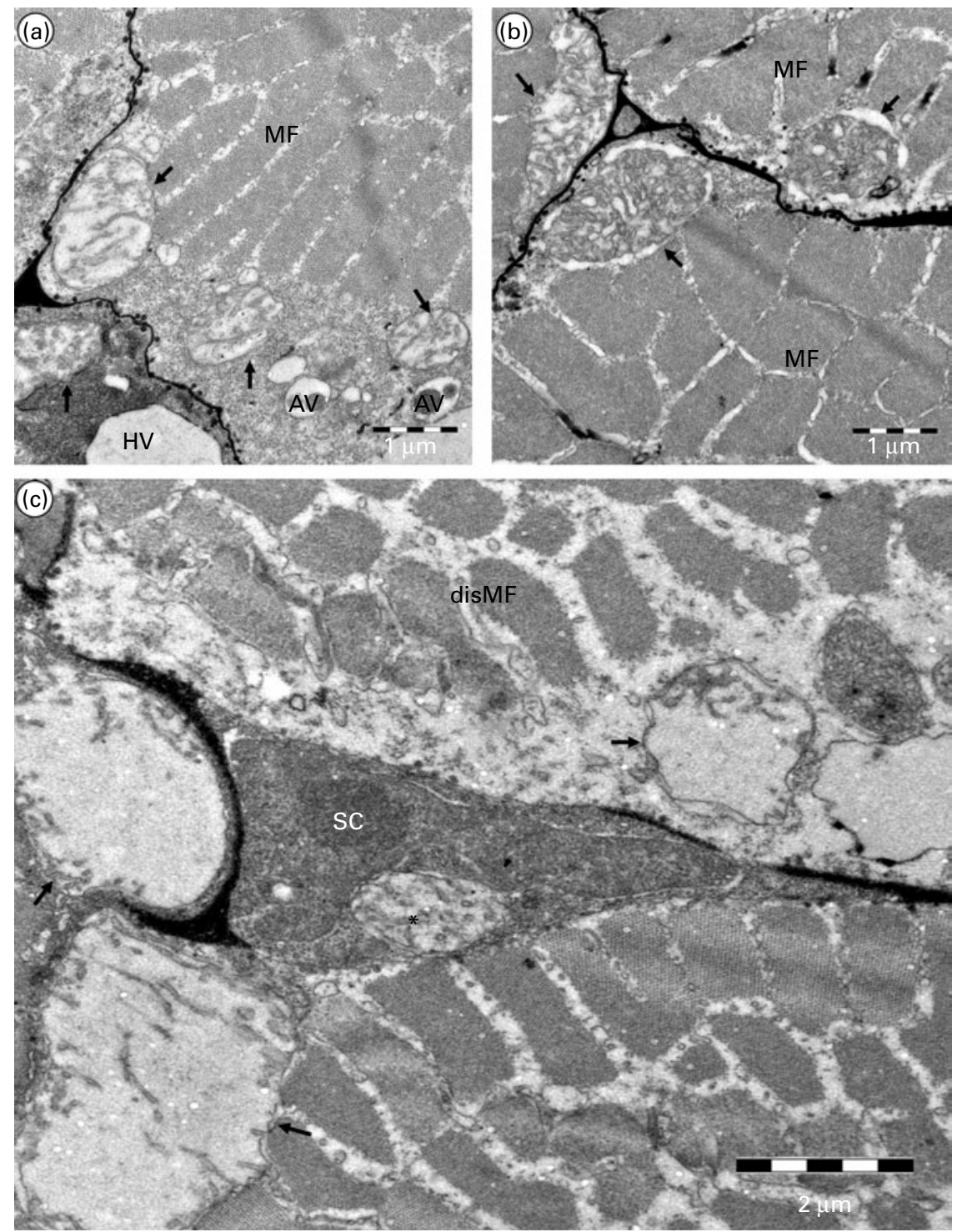

Fig. 2. Electromicrographs of transversal sections of sea bass larvae fed the diet $5 / 300$ ( $5 \mathrm{~g} \mathrm{DHA} / 100 \mathrm{~g}$ dry weight and $300 \mathrm{mg}$ vitamin E/100 g dry weight). (a) Damaged muscle fibre showing autophagic (AV) and hydropic vacuoles (HV) and swollen mitochondria (arrow; $8000 \times$ ). (b) Unaffected fibre where normal mitochondria can be observed $(\rightarrow ; 8000 \times)$. (c) Presence of a satellite cell (SC) with a mitochondrion $\left(^{*}\right)$ between two damaged muscle fibres, with the presence of vacuoles and degenerated mitochondria $(\rightarrow ; 5000 \times)$. MF, normal myofilaments; disMF, disarrayed myofilaments.

In the present study, an initial increase in the expression of each AOE was observed in all treatments at $26 \mathrm{dph}$, including the control group. Fernández-Díaz et al. ${ }^{(63)}$ found that the administration of inert diets to Solea senegalensis larvae produced increased CAT and SOD activity compared with larvae fed with Artemia. Therefore, the observed initial increase in expression could be due to the use of inert food.

In an attempt to dismutate superoxide anions and to decompose $\mathrm{H}_{2} \mathrm{O}_{2}$, increases in SOD, CAT and GPX expression were detected in fish larvae fed a high-DHA and Se-free diet. Similarly, exposure to high-DHA diets caused a significant increase in CAT and GPX in the larvae fed the Se-supplemented diets. Given that increases in SOD activity were less significant in Se-supplemented larvae, it can be concluded that $\mathrm{H}_{2} \mathrm{O}_{2}$ formation declined or that CAT activity was sufficient to remove
$\mathrm{H}_{2} \mathrm{O}_{2}$. These results agree with Monteiro et al. ${ }^{(64)}$ who observed that Se supplementation had a protective effect against oxidative stress caused by methyl parathion in Brycon cephalus, as denoted by a decrease in CAT and SOD activity. In contrast with these authors, Se supplementation did not increase the GPX level, or decreased GPX caused by methyl parathion. In mammals, it is likely that maintaining the activity of known selenoproteins, including GPX, is not the mechanism by which Se acts since it appears to be saturated at normal nutritional intakes. Thus, supranutritional levels of Se are required to reduce the incidence of human and animal diseases ${ }^{(65)}$. Therefore, it appears that other selenoproteins could be implicated in tissue antioxidant defence mechanisms. Among all selenoproteins, selenoprotein $\mathrm{P}$ seems to play an important role as an antioxidant defence in mammals ${ }^{(66)}$ by associating with 
(a)

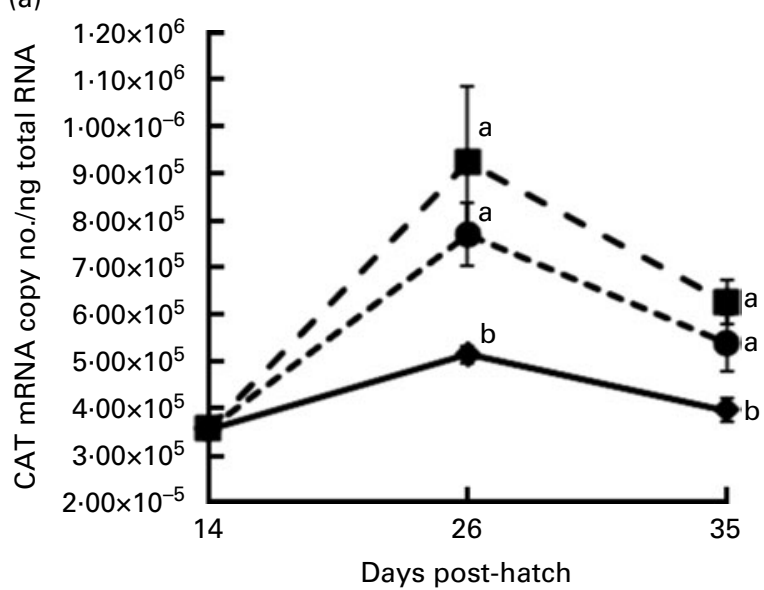

(c)

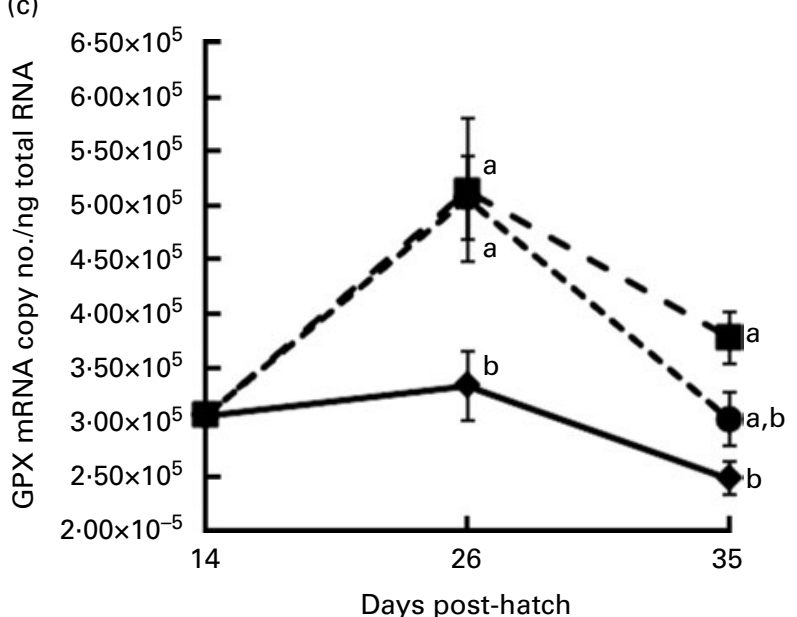

(e)

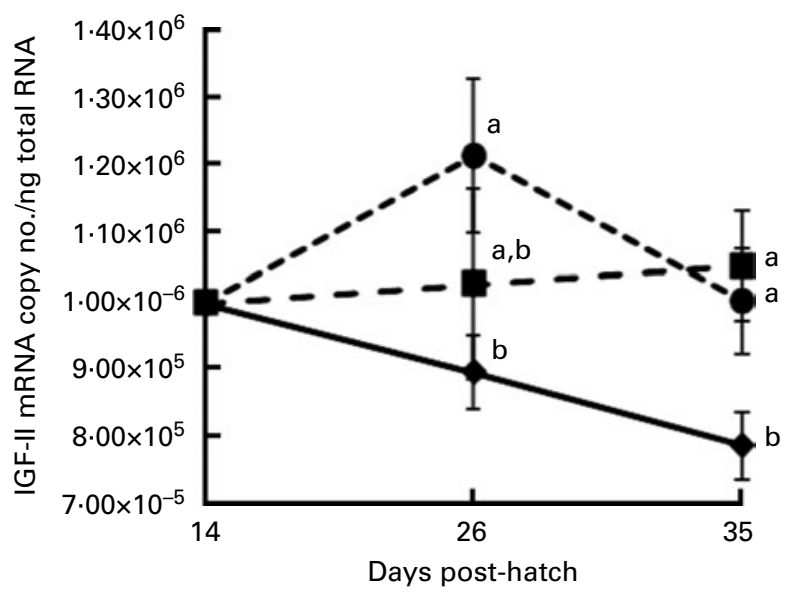

(b)

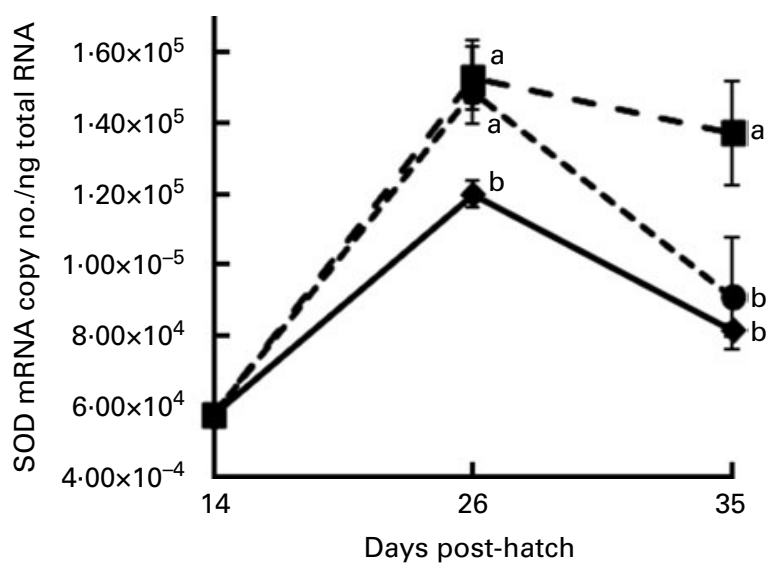

(d)

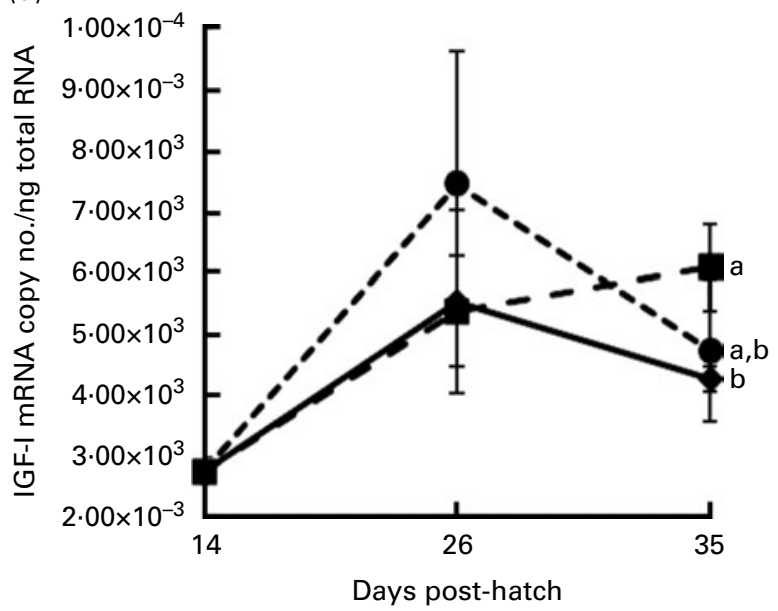

(f)

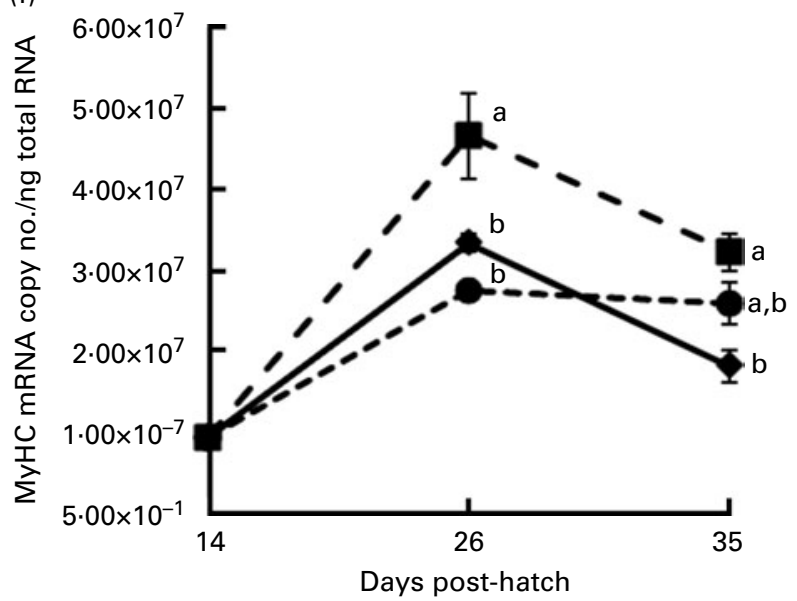

Fig. 3. (a) Catalase (CAT), (b) superoxide dismutase (SOD), (c) glutathione peroxidase (GPX), (d) insulin-like growth factor I (IGF-I), (e) insulin-like growth factor II (IGF-II) and (f) myosin heavy chain (MyHC) expression levels measured by real-time PCR in Dicentrarchus labrax larvae when fed the diets $1 / 150(\bullet ; 1 \mathrm{~g}$

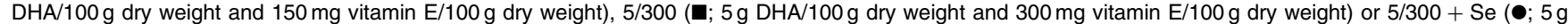
$\mathrm{DHA} / 100 \mathrm{~g}$ dry weight and $300 \mathrm{mg}$ vitamin $\mathrm{E} / 100 \mathrm{~g}$ dry weight supplemented with Se). mRNA copy number of each gene was normalised as a ratio to $100 \mathrm{ng}$ total RNA. Values are means, with standard deviations represented by vertical bars. ${ }^{a, b}$ Mean values with unlike letters were significantly different in gene expression among the treatments at given sampling points. 
Table 6. Effects of the dietary treatment, time and their interaction on the global gene expression

\begin{tabular}{lccc}
\hline & $\mathrm{D}$ & $\mathrm{T}$ & $\mathrm{D} \times \mathrm{T}$ \\
\hline$C A T$ & $* *$ & $* *$ & $\mathrm{NS}$ \\
SOD & $* *$ & $* *$ & $*$ \\
$G P X$ & $* \star$ & $* *$ & $\mathrm{NS}$ \\
IGF-I & $\mathrm{NS}$ & $\mathrm{NS}$ & $*$ \\
IGF-II & $* *$ & $*$ & $\mathrm{NS}$ \\
MyHC & $* *$ & $* *$ & $\mathrm{NS}$ \\
\hline
\end{tabular}

$\mathrm{D}$, diet; T, time; $C A T$, catalase; $S O D$, superoxide dismutase; GPX, glutathione peroxidase; IGF-I, insulin-like growth factor I; IGF-II, insulin-like growth factor II; MyHC, myosin heavy chain.

${ }^{\star} P \leq 0.05,{ }^{* \star} P \leq 0.01$.

endothelial cells. Previous studies in zebrafish (Danio rerio) indicate that selenoprotein $\mathrm{P}$ is utilised to a larger extent than in human subjects, as it is encoded by two genes and has seventeen selenocysteine residues, the largest number of selenocysteine residues found in any known protein ${ }^{(67,68)}$. In consequence, the action of selenoprotein $\mathrm{P}$ or any other selenoproteins could be critical as an antioxidant defence against lipid $\mathrm{H}_{2} \mathrm{O}_{2}$ in sea bass larvae when Se requirements are covered. Thus, further studies are required to clarify the antioxidant mode of Se action in marine fish larvae.

As observed in our previous studies ${ }^{(12,24)}$, high dietary DHA levels caused pathological changes in sea bass larvae muscle. However, in the present study, inclusion of Se proved to be efficient in controlling the damage caused by ROS, reducing the incidence of muscle injury to almost half as compared with the 5/300 diet. Moreover, certain properties of muscle may render it especially susceptible to ROS injury ${ }^{(1)}$. For instance, muscle is prone to oxidative injury as a result of increased electron flux due to its requirement and ability to undertake rapid and coordinated changes in energy supply and oxygen flux during contraction ${ }^{(69)}$. There is also a very high concentration of myoglobin in the muscle, and it is known that such a haem-containing protein may confer greater sensitivity to free radical-induced damage by the conversion of $\mathrm{H}_{2} \mathrm{O}_{2}$ to a more reactive species ${ }^{(70)}$. Furthermore, the requirement of skeletal muscle membranes for phospholipids containing large proportions of PUFA may render those membranes particularly susceptible to oxidative stress ${ }^{(71)}$. Finally, low Se accumulation in muscular tissues will make this tissue more susceptible to oxidative damage ${ }^{(64,72)}$. However, interaction of LC-PUFA with other cellular components should be taken into account to complete the scenario. In this sense, studies using juvenile salmon fed with high-EPA and DHA diets showed loss of mitochondrial $\beta$-oxidation, reduced lipid deposition and apoptosis in white adipose tissue, indicating that high supplementation rates of these LC-PUFA may lead to oxidative stress ${ }^{(73)}$.

IGF-I and IGF-II are polypeptides well known for promoting proliferation and differentiation in many vertebrates with nutritional status having a profound effect on the IGF system in fish ${ }^{(74)}$. However, most nutritional studies have focused on the effects of food restriction ${ }^{(32,33,75)}$, dietary protein or carbohydrate content ${ }^{(76,77)}$ and probiotics ${ }^{(78)}$, whereas little information is known about the effect of lipids on this system.
Moreover, no information exists about the effect of oxidative stress on IGF in fish larvae. In the present study, an increase in IGF-I and IGF-II in the larvae fed the 5/300 diet was observed, especially when no Se was added, suggesting oxidative stress may play a role in the expression of these growth factors. Accordingly, the larvae fed the highest content of DHA showed a higher incidence of muscular lesions and the presence of abundant satellite cells. Satellite cells are able to regenerate damaged muscle by forming new myofibres by fusing to existing muscle fibres or fusing together ${ }^{(79)}$. It is known that to control the satellite cell population, growth factors are required ${ }^{(80)}$. In mammals, IGF-I appears to utilise multiple signalling pathways in the regulation of the satellite cell pool such as the mitogenactivated protein or phosphatidylinositol-3-OH kinase ${ }^{(81,82)}$. In agreement with this, Pozios et al. ${ }^{(83)}$ showed that IGF-II and IGF-I potently activate cell proliferation and DNA synthesis in embryonic zebrafish cells via mitogen-activated protein and phosphatidylinositol-3-OH kinase, suggesting that the increase in IGF-I mRNA copies observed in the present study in the larvae with the highest incidence of muscular lesions could be due to the regeneration process carried out by satellite cells. Similarly, the mitogenic effect of IGF in fish has also been described in cultured muscle cells from rainbow trout ${ }^{(84)}$.

Late markers of myogenesis include the myofibrillar protein MyHC. By monitoring the expression patterns of this marker gene, the effect that nutritional status has on muscle growth can be determined ${ }^{(29)}$. Regeneration of fish muscle has only rarely been described. Rowlerson et al. ${ }^{(85)}$ demonstrated a vigorous regeneration in juvenile sea bream (Sparus aurata) after mechanical injury, with myosin expression in regenerating fibres resembling that seen in newly produced fibres in postlarval white muscle. In the present study, a higher expression of myosin was observed in the 5/300 larvae, especially when Se was not added to the diets with a positive correlation observed between the incidence of muscular lesions and myosin mRNA copies at $35 \mathrm{dph}\left(y=2 \times 10^{-6} x-29 \cdot 567 ; R^{2}\right.$ 0.9133).

In the present study, the high levels of AOE and MDA content observed in the 5/300 larvae demonstrate an adaptive response in attempting to neutralise the generated ROS. Moreover, a reactive response was observed by the increase in IGF and MyHC expression in larval tissues, suggesting regenerative processes in the injured muscle. Organic Se proved to enhance the cell antioxidant capacity, protecting muscle, as shown by the decrease in the incidence of muscular lesions, MDA content and AOE expression. Therefore, when high levels of LC-PUFA are included in sea bass larvae microdiets, an adequate combination of dietary $\alpha$-tocopherol and Se must be included to avoid the appearance of oxidative stress in larval tissues and favour culture performance.

\section{Acknowledgements}

M. B. B. was supported by a grant given by the Cabildo Insular de Gran Canaria. The present study was funded by the Spanish Ministry of Sciences and Education (AGL2009-14661). The authors are thankful to Dr Matthew Sprague for his assistance in proof reading the manuscript. Acknowledgments are due to 
Instituto de Acuicultura de Torre la Sal that kindly provided the sea bass eggs, Croda Company and Alltech that provided DHA and EPA 50 and the Se yeast, respectively. The authors disclose no conflicts of interest. M. B. B. carried out the experiment, performed all analyses, participated in the interpretation of the results and drafted the manuscript. M. J. C. and M. I. participated in the animal experimental design, interpretation of the results and the preparation of the manuscript. R. S. and T. B.-S. participated in the animal feeding and sampling. E. A. collaborated to formulate and prepare the experimental microdiets. G. T. supervised the molecular biology analysis and J. G. B. supervised the vitamin $\mathrm{E}$ and Se analysis.

\section{References}

1. Rando TA (2002) Oxidative stress and the pathogenesis of muscular dystrophies. Am J Phys Med Rehab 81, 175-186.

2. Halliwell B \& Gutteridge JMC (1996) Lipid peroxidation: a radical chain reaction. In Free Radicals in Biology and Medicine, pp. 188-266 [B Halliwell and JMC Gutteridge, editors]. Oxford: Clarendon Press.

3. Bell JG, Cowey CB, Adron JW, et al. (1987) Some effects of selenium deficiency on enzyme activities and indices of tissue peroxidation in Atlantic salmon parr (Salmo salar). Aquaculture 65, 43-54.

4. Wilhelm-Filho D (1996) Fish antioxidant defenses - a comparative approach. Braz J Med Biol Res 29, 1735-1742.

5. Lygren B, Hamre K, Waagbø R, et al. (1999) Effect of dietary pro- and antioxidants on some protective mechanisms and health parameters in Atlantic salmon. J Aquat Anim Health 11, 211-221.

6. Bell JG, McEvoy J, Tocher DR, et al. (2000) Depletion of $\alpha$ tocopherol and astaxanthin in Atlantic salmon (Salmo salar) affects autoxidative defence and fatty acid metabolism. J Nutr 130, 1800-1808.

7. Díaz ME, Furné M, Trenzado CE, et al. (2010) Antioxidant defences in the first life phases of the sturgeon Acipenser naccarii. Aquaculture 307, 123-129.

8. Hamre K (2010) Metabolism, interactions, requirements and functions of vitamin E in fish. Aquacult Nutr 17, 98-115.

9. Mourente G, Tocher DR, Díaz E, et al. (1999) Relationships between antioxidants, antioxidant enzyme activities and lipid peroxidation products during early development in Dentex dentex eggs and larvae. Aquaculture 179, 309-324.

10. Atalah E (2008) Importance of the proportions of dietary polyunsaturated fatty acids and antioxidants in larval development of marine fish. PhD Thesis, University of Las Palmas de Gran Canaria.

11. Penglase S, Nordgreen A, Van der Meeren T, et al. (2010) Increasing the level of selenium in rotifers (Brachionus plicatilis 'Cayman') enhances the mRNA expression and activity of glutathione peroxidase in cod (Gadus morbua L.) larvae. Aquaculture 306, 259-269.

12. Betancor MB, Atalah E, Caballero MJ, et al. (2011) $\alpha$-Tocopherol in weaning diets for European sea bass (Dicentrarchus labrax) improves survival and reduces tissue damage caused by excess dietary DHA contents. Aquacult Nutr 13, e112-e122.

13. Lall SP \& Bishop FJ (1977) Studies on mineral and protein utilization by Atlantic salmon (Salmo salar) grown in sea water. Fisheries and Marine Service, Environment Canada, Ottawa, ON, Technical Report No. 688, pp. 16.

14. Halver JE (2002) The vitamins. In Fish Nutrition, 2nd ed., pp. 62-132 [JE Halver and R Hardy, editors]. New York: Academic Press.
15. Felton SP, Landolt ML \& Grace R (1996) Effects of selenium dietary enhancement on hatchery-reared coho salmon, Oncorbynchus kisutch (Walbaum), when compared with wild coho: hepatic enzymes and seawater adaptation evaluated. Aquacult Res 27, 135-142.

16. Arteel GE \& Sies H (2001) The biochemistry of selenium and the glutathione system. Environ Toxicol Phar 10, 153-158.

17. Poston HA, Combs GF Jr \& Leibovitz L (1976) Vitamin E and selenium interrelations in the diet of Atlantic salmon (Salmo salar): gross, histological and biochemical deficiency signs. J Nutr 106, 892-904.

18. Bell JG \& Cowey CB (1985) Roles of vitamin E and selenium in the prevention of pathologies related to fatty acid oxidation in salmonids. In Nutrition and Feeding in Fish, pp. 333-347 [CB Cowey, AM Mackie and JG Bell, editors]. London: Academic Press.

19. Bell JG, Pirie BJS, Adron JW, et al. (1986) Some effects of selenium deficiency on glutathione peroxidase (EC 1.11.1.9) activity and tissue pathology in rainbow trout (Salmo gairdneri). Br J Nutr 55, 305-311.

20. Gatlin DM, Poe WE \& Wilson RF (1986) Effects of singular and combined dietary deficiencies of selenium and vitamin $\mathrm{E}$ on fingerling channel catfish (Ictalurus punctatus). J Nutr 116, 1061-1067.

21. Lin YH \& Shiau SY (2009) Mutual sparing of dietary requirements for alpha-tocopherol and selenium in grouper, Epinephelus malabaricus. Aquaculture 294, 242-245.

22. McEvoy LA, Naess T, Bell JG, et al. (1998) Lipid and fatty acid composition of normal and malpigmented Atlantic halibut (Hippoglossus hippoglossus) fed enriched Artemia: a comparison with fry fed wild copepods. Aquaculture 163, 237-250.

23. Evjemo JO, Reitan KL \& Olsen Y (2003) Copepods and live food organisms in the larval rearing of halibut larvae (Hippoglossus hippoglossus L.) with special emphasis on the nutritional value. Aquaculture 227, 191-210.

24. Betancor MB, Caballero MJ, Benítez-Santana T, et al. (2012) Oxidative status and histological changes in sea bass larvae muscle in response to high dietary content of DHA. J Fish Dis (In the press).

25. Johnston IA, Abercromby M, Vieira VL, et al. (2004) Rapid evolution of muscle fibre number in post-glacial populations of Arctic charr Salvelinus alpinus. J Exp Biol 207, 4343-4360.

26. Allen RE \& Boxhorn LK (1989) Regulation of skeletal muscle satellite cell proliferation and differentiation by transforming growth-factors beta, insulin-like growth factor I and fibroblast growth factor. J Cell Physiol 138, 311-315.

27. Johnston IA (1999) Muscle development and growth: potential implications for flesh quality in fish. Aquaculture 177, 99-115.

28. Goldspink G, Wilkes D \& Ennion S (2001) Myosin expression during ontogeny, post-hatching growth and adaptation. In Muscle Development and Growth, pp. 43-66 [IA Johnston, editor]. San Diego, CA: Academic Press.

29. Bower NI, Li X, Taylor R, et al. (2008) Switching to fast growth: the insulin-like growth factor (IGF) system in skeletal muscle of Atlantic salmon. J Exp Biol 211, 3859-3870.

30. Duan C \& Plisetskaya EM (1993) Nutritional regulation of insulin-like growth factor-I mRNA expression in salmon tissues. J Endocrinol 139, 243-252.

31. Matthews SJ, Kinhult AK, Hoeben P, et al. (1997) Nutritional regulation of insulin-like growth factor I mRNA expression in barramundi, Lates calcarifer. J Mol Endocrinol 18, 273-276.

32. Terova G, Rimoldi S, Chini V, et al. (2007) Cloning and expression analysis of insulin-like growth factor I and II in 
liver and muscle of sea bass (Dicentrarchus labrax, L.) during long-term fasting and refeeding. J Fish Biol $\mathbf{7 0}$, 219-233.

33. Hevrøy EM, Azpeleta C, Shimizu M, et al. (2011) Effects of short-term starvation on ghrelin, GH-IGF system and IGFbinding proteins in Atlantic salmon. Fish Physiol Biochem 37, 217-232.

34. Chauvigné F, Gabillard JC, Weil C, et al. (2003) Effect of refeeding on IGFI, IGFII, IGF receptors, FGF2, FGF6, and myostatin mRNA expression in rainbow trout myotomal muscle. Gen Comp Endocrinol 132, 209-215.

35. Watabe S (1999) Myogenic regulatory factors and muscle differentiation during ontogeny in fish. J Fish Biol 55, 1-18.

36. Silva P, Rowlerson AM, Valente LMP, et al. (2008) Muscle differentiation in blackspot seabream (Pagellus bogaraveo, Brunnich): histochemical and immunohistochemical study of the fibre types. Tissue Cell 40, 447-458.

37. Liu J, Caballero MJ, Izquierdo MS, et al. (2002) Necessity of dietary lecithin and eicosapentaenoic acid for growth, survival, stress resistance and lipoprotein formation in gilthead sea bream Sparus aurata. Fish Sci 68, 1165-1172.

38. AOAC (1995) Official Methods of Analysis, 16th ed. Washington, DC: AOAC International.

39. Folch J, Lees M \& Sloane Stanley GH (1957) A simple method for the isolation and purification of total lipides from animal tissues. J Biol Chem 226, 497-509.

40. Christie WW (1982) Lipid Analysis. Oxford: Pergamon Press.

41. Izquierdo MS, Arakawa T, Takeuchi T, et al. (1992) Effect of $n$-3 HUFA levels in Artemia on growth of larval Japanese flounder (Paralichthys olivaceus). Aquaculture 105, 73-82.

42. McMurray CH, Blanchflower WJ \& Rice DA (1980) Influence of extraction techniques on determination of $\alpha$-tocopherol in animal feedstuffs. J Assoc Off Anal Chem 63, 1258-1261.

43. Cowey CB, Adron JW, Walton MJ, et al. (1981) Tissue distribution, uptake and requirement for $\alpha$-tocopherol of rainbow trout (Salmo gairdneri) fed diets with a minimal content of unsaturated fatty acids. J Nutr 111, 1556-1567.

44. Burk RF, Trumble MJ \& Lawrence RA (1980) Rat hepatic cytosolic GSH-dependent enzyme protection against lipid peroxidation in the NADPH microsomal lipid peroxidation system. Biochim Biophys Acta 618, 35-41.

45. Martoja R \& Martoja Pearson M (1970) Técnicas de Histología Animal (Animal Histology Techniques). Barcelona: TorayMasson, SA.

46. Hoffman EO, Flores TR, Coover J, et al. (1983) Polychrome stains for high resolution light microscopy. Lab Med 14, 779-781.

47. Combs GF Jr \& Scott ML (1974) Dietary requirements for vitamin $\mathrm{E}$ and selenium measured at the cellular level in the chick. J Nutr 104, 1292-1296.

48. Hamre K, Srivastava A, Rønnestad I, et al. (2008) Several micronutrients in the rotifer Brachionus sp. may not fulfil the nutritional requirements of marine fish larvae. Aquac Nutr 14, 51-60.

49. Van der Meeren $\mathrm{T}$, Olsen RE, Hamre $\mathrm{K}$, et al. (2008) Biochemical composition of copepods for evaluation of feed quality in production of juvenile marine fish. Aquaculture 274, 375-397.

50. National Research Council (NRC) (1993) Nutrient Requirements of Fish. Washington, DC: National Academy Press pp. 62-63.

51. Hilton JW, Hodson PV \& Slinger SJ (1980) The requirement and toxicity of selenium in rainbow trout (Salmo gairdneri). J Nutr 110, 2527-2535.
52. Lin YH \& Shiau SY (2005) Dietary selenium requirement of grouper, Epinephelus malabaricus. Aquaculture 250 , $356-363$.

53. Jaramillo F, Peng L \& Gatlin D (2009) Selenium nutrition of hybrid striped bass (Morone chrysops $\times M$. Saxatalis) bioavailability, toxicity and interaction with vitamin $\mathrm{E}$. Aqua Nutr 15, 160-165.

54. Tinggi U (2003) Essentiality and toxicity of selenium and its status in Australia: a review. Toxicol Lett 137, 103-110.

55. Rider SA, Davies SJ, Jha AN, et al. (2010) Bioavailability of co-supplemented organic and inorganic zinc and selenium sources in white fishmeal-based rainbow trout (Oncorbynchus mykiss) diet. J Anim Physiol Anim Nutr 94, 99-110.

56. Kiron V, Puangkaew J, Ishizaka K, et al. (2004) Antioxidant status and nonspecific immune response in rainbow trout (Oncorbynchus mykiss) fed two levels of vitamin E along with three lipid sources. Aquaculture 234, 361-379.

57. Puangkaew J, Kiron V, Satoh S, et al. (2005) Antioxidant defense of rainbow trout (Oncorbynchus mykiss) in relation to dietary $n-3$ highly unsaturated fatty acids and vitamin $\mathrm{E}$ contents. Comp Biochem Physiol C 140, 187-196.

58. Ji H, Li J \& Liu P (2011) Regulation of growth performance and lipid metabolism by dietary $n-3$ highly unsaturated fatty acids in juvenile grass carp, Ctenopharyngodon idellus. Comp Biochem Physiol B 159, 49-56.

59. Kim S, Ji K, Lee S, et al. (2011) Perfluorooctane sulfonic acid (PFOS) exposure increases cadmium toxicity in early life stage of zebrafish (Danio rerio). Environ Toxicol Chem 38 , 870-877.

60. Peters LD \& Livingstone DR (1996) Antioxidant enzyme activities in embryologic and early larval stages of turbot. J Fish Biol 49, 986-997.

61. Tovar-Ramírez D, Mazurais D, Gatesoupe JF, et al. (2010) Dietary probiotics live yeast modulate antioxidant enzyme activities and gene expression of sea bass (Dicentrarchus labrax) larvae. Aquaculture 300, 142-147.

62. Zhang H, Mu Z, X LM, et al. (2009) Dietary lipid level induced antioxidant response in Manchurian trout, Brachymystax lenok (Pallas) larvae. Lipids 44, 643-654.

63. Fernández-Díaz C, Kopecka I, Canavete JP, et al. (2006) Variations on development and stress resistance in Solea senegalensis larvae fed on live and microencapsulated diets. Aquaculture 251, 573-584.

64. Monteiro DA, Rantin FT \& Kalinin AL (2009) The effects of selenium on oxidative stress biomarkers in the freshwater characid fish matrinxa, Brycon cephalus (Günther, 1869) exposed to organophosphate insecticide Folisuper $600 \mathrm{BR}^{\circledR}$ (methyl parathion). Comp Biochem Physiol C 149, 40-49.

65. Brown KM \& Arthur JR (2001) Selenium, selenoproteins and human health: a review. Public Health Nutr 4, 593-599.

66. Burk RF, Hill KE, Boeglin ME, et al. (1997) Selenoprotein P associates with endothelial cells in rat tissues. Histochem Cell Biol 108, 11-15.

67. Tubajeva RM, Ransom DG, Harney JW, et al. (2000) Expression and characterization of nonmammalian selenoprotein $\mathrm{P}$ in the zebrafish, Danio rerio. Genes Cells 5, 897-903.

68. Kryukov GV \& Gladyshev VN (2000) Selenium metabolism in zebrafish: multiplicity of selenoprotein genes and expression of a protein containing 17 selenocysteine residues. Genes Cells 5, 1049-1060.

69. Haycock JW, Jones P, Harris JB, et al. (1996) Differential susceptibility of human skeletal muscle proteins to free radical induced oxidative damage: a histochemical, inmunocytochemical and electron microscopical study in vitro. Acta Neuropathol 92, 331-340. 
70. Ostdal H, Skibsted LH \& Andersen HJ (1997) Formation of long-lived protein radicals in the reaction between $\mathrm{H}_{2} \mathrm{O}_{2}-$ activated metamyoglobin and others proteins. Free Rad Biol Med 23, 754-761.

71. Murphy ME \& Kehrer JP (1989) Oxidative stress and muscular dystrophy. Chem Biol Interact 69, 101-178.

72. Elia AC, Prearo M, Pacini N, et al. (2011) Effects of selenium on growth, accumulation and antioxidant response in juvenile carp. Ecotoxicol Environ Saf 74, 166-173.

73. Todorčević M, Kjær M, Djaković N, et al. (2009) n-3 HUFAs affect fat deposition, susceptibility to oxidative stress, and apoptosis in Atlantic salmon visceral adipose tissue. Comp Bichem Physiol B 152, 135-143.

74. Duan C (1998) Nutritional and developmental regulation of insulin-like growth factors in fish. J Nutr 128, 306S-314S.

75. Moriyama S, Swanson P, Nishi M, et al. (1994) Development of a homologous radioimmunoassay for coho salmon insulin-like growth factor-I. Gen Comp Endocrinol 96, 149-161.

76. Enes P, Sánchez-Gurmaches J, Navarro I, et al. (2010) Role of insulin and IGF-I on the regulation of glucose metabolism in European sea bass (Dicentrarchus labrax) fed with different dietary carbohydrate levels. Comp Biochem Physiol A 157, 346-353.

77. Pérez-Sánchez J, Martipalanca H \& Kaushik SJ (1995) Ration size and protein intake affect circulating growth hormone concentration, hepatic growth binding and plasma insulinlike growth factor I immunoreactivity in a marine teleost, the gilthead sea bream (Sparus aurata). J Nutr 125, 546-552.
78. Carnevali O, de Vivo L, Sulpizio R, et al. (2006) Growth improvement by probiotic in European sea bass juveniles (Dicentrarchus labrax. L.), with particular attention to IGF-1, myostatin and cortisol gene expression. Aquaculture 258, $430-438$.

79. Schultz E \& McCormick KM (1994) Skeletal muscle satellite cells. Rev Physiol Biochem Pharmacol 123, 213-257.

80. Seale P \& Rudnicki MA (2000) A new look at the origin, function and 'stem-cell' status of muscle satellite cells. Dev Biol 218, 115-124.

81. Coolican SA, Samuel DS, Ewton DZ, et al. (1997) The mitogenic and myogenic actions of insulin-like growth factors utilize distinct signalling pathways. J Biol Chem 272, 6653-6662

82. Semsarian C, Wu MJ, Ju YK, et al. (1999) Skeletal muscle hypertrophy is mediated by a $\mathrm{Ca}^{2+}$-dependent calcineurin signaling pathway. Nature 400, 576-581.

83. Pozios KC, Ding J, Degger B, et al. (2001) IGFs stimulate zebrafish cell proliferation by activating MAP kinase and PI3-kinase-signalling pathways. Am J Physiol 280, R1230-R1239.

84. Castillo J, Codina M, Martínez ML, et al. (2004) Metabolic and mitogenic effects of IGF-I and insulin on muscle cells of rainbow trout. Am J Physiol Integr Comp Physiol 286, 935-941.

85. Rowlerson A, Radaelli G, Mascarello F, et al. (1997) Regeneration of skeletal muscle in two teleost fish: Sparus aurata and Brachydanio rerio. Cell Tissue Res 289, 311-322. 